\title{
Nd and Sr Isotopic Study of the Bay of Islands Ophiolite Complex and the Evolution of the Source of Midocean Ridge Basalts
}

\author{
STEIN B. JACOBSEN AND G. J. WASSERbURG
}

\author{
The Lunatic Asylum of the Charles Arms Laboratory, Division of Geological and Planetary Sciences \\ California Institute of Technology, Pasadena, California 91125
}

\begin{abstract}
Two Sm-Nd internal isochrons for pyroxene gabbros of the Bay of Islands Ophiolite Complex give well-defined ages of $508 \pm 6 \mathrm{~m}$.y. and $501 \pm 13 \mathrm{~m}$.y. with initial ${ }^{143} \mathrm{Nd} /{ }^{144} \mathrm{Nd}$ of $\varepsilon_{\mathrm{Nd}}=+7.7 \mp 0.1$ and $\varepsilon_{\mathrm{Nd}}$ $=+7.5 \mp 0.2$, respectively. Total rock samples from pillow basalts, sheeted dikes, trondhjemites, hornblende gabbros, pyroxene gabbros, and an orthopyroxenite layer from the harzburgite give initial $\varepsilon_{\mathrm{Nd}}$ in the range from +6.5 to +8.1 with an average value of +7.6 . The initial ${ }^{87} \mathrm{Sr} /{ }^{86} \mathrm{Sr}$ obtained on a pyroxenegabbro is $\varepsilon_{\mathrm{Sr}}=-19.3 \pm 0.3$, which is typical of oceanic samples. However, the initial ${ }^{87} \mathrm{Sr} /{ }^{86} \mathrm{Sr}$ within the different phases of the complex is found to be highly variable ( $\sim 52 \varepsilon$ units) and shows the effect of sea water alteration. The $\varepsilon_{\mathrm{Nd}}$ values demonstrate a clear oceanic affinity for the Bay of Islands complex and support earlier interpretations made on the basis of structure and geochemistry. The magnitudes of the initial $\varepsilon_{\mathrm{Nd}}$ values $(+7.6)$ are somewhat smaller than for typical present-day midocean ridge basalts (MORB) $(+10)$. This is most likely due to differential evolution over the past 0.5 aeon of the oceanic mantle relative to the bulk earth. The observed shift is quantitatively what should be expected for a simple single-stage evolution. For a model with a single differentiation event at time $T_{D}$ to produce the depleted mantle, both $\mathrm{Sm}-\mathrm{Nd}$ and $\mathrm{Rb}-\mathrm{Sr}$ data for MORB and the Bay of Islands Complex give $T_{D} \approx 1.8$ aeons. This age is, however, interpreted as the mean age of the MORB source and does not refer to a unique event. The total time for producing this source by a uniform process would be of the order of 3.6 aeons. The Nd isotopic signature of oceanic crust is clearly present in this Paleozoic ophiolite and suggests that typical high- $\varepsilon_{N d}$ reservoirs are sources of oceanic crust through the Phanerozoic. This implies relatively rapid turnover between oceanic crust and mantle sources and a good mixing of oceanic mantle for the past 1.0 aeon, including contributions from recycled continental materials. These data indicate that the major distinction between oceanic basalts and continental basalts observed in recent rocks is also preserved through the Phanerozoic. These isotopic differences clearly imply a long time distinction between the magma sources of these basalt types. It should be possible to apply the distinctive $\varepsilon_{\mathrm{Nd}}$ values of oceanic crust and mantle to identify old obducted oceanic segments on continental blocks.
\end{abstract}

\section{INTRODUCTION}

There is a considerable amount of $\mathrm{Nd}, \mathrm{Sr}$, and $\mathrm{Pb}$ isotopic data available on both old and young continental crustal rocks. These data have contributed significantly to our understanding of the evolution of the continental crust. For the oceanic crust, only very young samples have been measured because the present-day oceanic crust is geologically very young ( $\leq 0.18$ aeon) ( 1 aeon $=1 \mathrm{AE}=10^{9}$ years) in comparison with the continental crust (0-3.8 aeon). Remnants of oceanic type crust appear to be present within the continental crust back through the Phanerozoic, although they are in places difficult to recognize. Very little is known, however, about oceanic magma genesis in the Precambrian, and clear evidence for preserved Precambrian oceanic crust is at present lacking.

Constraints on the evolution of oceanic crust and mantle are provided by available $\mathrm{Rb}-\mathrm{Sr}, \mathrm{U}-\mathrm{Th}-\mathrm{Pb}$, and $\mathrm{Sm}-\mathrm{Nd}$ data on young oceanic basalts. It is well known that $\mathrm{Rb} / \mathrm{Sr}$ ratios in many midocean ridge basalts (MORB) are too low to support their ${ }^{87} \mathrm{Sr} /{ }^{86} \mathrm{Sr}$ ratios [Tatsumoto et al., 1965]. Assuming that $\mathbf{R b} / \mathrm{Sr}$ ratios of MORB are not less than those for their source regions, it follows that the mantle source for MORB has been depleted in $\mathrm{Rb}$ in relation to $\mathrm{Sr}$ [Tatsumoto et al., 1965; Gast, 1968]. Gast [1968] proposed that MORB are derivatives of a mantle which has been left as a residue from previous partial melting in the mantle.

DePaolo and Wasserburg [1976a, b, 1979c] showed that continental flood basalts (CFB) are derived from reservoirs which

Copyright $(\mathcal{1} 1979$ by the American Geophysical Union. have condritic $\mathrm{Sm} / \mathrm{Nd}$ ratios and that MORB were derived from ancient reservoirs which are distinct from those of the continental basalts and characterized by higher $\mathrm{Sm} / \mathrm{Nd}$. DePaolo and Wasserburg [1976b] and O'Nions et al. [1977] also showed that for young volcanic rocks with ${ }^{87} \mathrm{Sr} /{ }^{86} \mathrm{Sr}$ ratios less than $\sim 0.705$ there is a strong correlation between initial ${ }^{143} \mathrm{Nd} /{ }^{144} \mathrm{Nd}$ and initial ${ }^{87} \mathrm{Sr} /{ }^{86} \mathrm{Sr}$. The correlation is broadly consistent with known solid/liquid distribution coefficients which indicate that a residue after partial melting would be expected to have had its $\mathrm{Sm} / \mathrm{Nd}$ ratio increased and its $\mathrm{Rb} / \mathrm{Sr}$ ratio decreased. However, such a strong correlation was not expected.

The timing of the fractionation events in the MORB sources is of considerable current interest. The data have been interpreted in terms of a single mantle fractionation event. $\mathrm{Pb}$ $\mathrm{Pb}$ two-stage model isochrons [Church and Tatsumoto, 1975; Sun and Jahn, 1975] and Rb-Sr 'mantle isochrons' [Brooks et $a l ., 1976 a, b]$ have been used to infer differentiation ages of the order of 1.5-1.8 aeons, while Sm-Nd model ages for primitive oceanic tholeiites suggest a differentiation age of $\sim 1.1$ aeons for the MORB source [Carlson et al., 1978]. However, the data do not exactly fit a two-stage model, so multistage models or continuous fractionation models have also been favored [O'Nions et al., 1978b].

All the above cited data were obtained on young oceanic basalts. There is at present no isotopic study available on ancient oceanic crust. Most geologists now agree upon an oceanic origin for the ophiolites found in many mountain belts. Ophiolites are believed to be pieces of oceanic crust and 


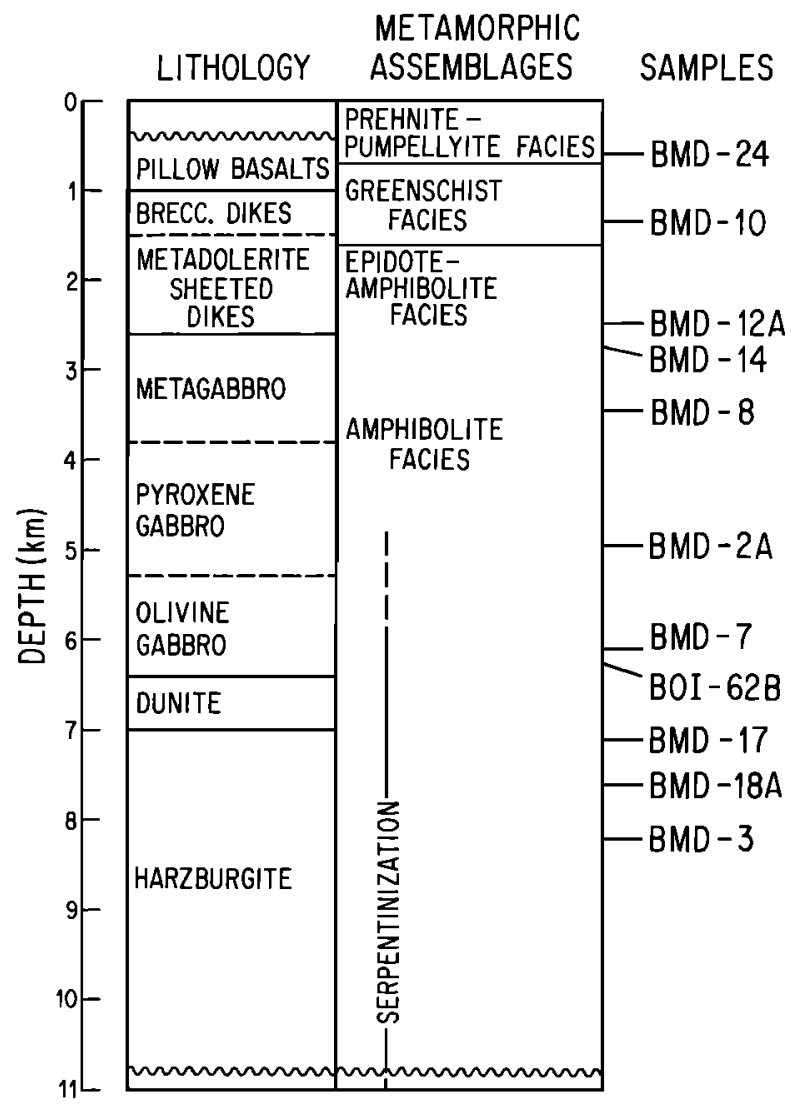

Fig. 1. Idealized stratigraphy of the Blow-Me-Down massif after Salisbury and Christensen [1978]. The sample numbers show the location of samples in the stratigraphy.

mantle emplaced on the continent during the early stages of orogenesis resulting from plate collision. Studies of thickness, structure, seismic wave velocities, and geochemistry of ophiolite suites indicate a close analogy between ophiolites and oceanic crust and mantle formed at midocean ridges (for a review, see Coleman [1977]). Spreading plate margins occur also in small ocean basins, and these are of considerable importance as proposed origins of ophiolite complexes [Dewey and Bird, 1971; Karson and Dewey, 1978]. We have therefore carried out a Nd and $\mathrm{Sr}$ isotopic study of an early Paleozoic ophiolite, the Bay of Islands Complex, in order to (1) characterize the source of the magmas which formed this ophiolite, (2) determine if these magmas were derived from a mantle reservoir similar to that of MORB, (3) determine the age by the internal Sm-Nd mineral isochron method and establish whether or not a Sm-Nd whole rock isochron exists for the complex, and (4) discuss the evolution of the oceanic mantle through time and attempt to understand the significance of proposed differentiation ages of the MORB source.

\section{The Blow-Me-Down Massif of THE Bay of IsLands COMPLEX}

\section{Geology}

The Bay of Islands Complex $\left(\sim 750 \mathrm{~km}^{2}\right)$ is the best preserved of the early Paleozoic ophiolites in the Appalachians. It is located on the western coastline of Newfoundland and consists of four isolated massifs. The Blow-Me-Down massif is structurally the least complicated and is stratigraphically nearly complete (Figure 1). The geology of the Blow-MeDown massif has been described by Smith [1958], Williams and Malpas [1972], Williams [1973], and Salisbury and Chris- tensen [1978]. Salisbury and Christensen [1978] showed that the seismic velocity structure of the massif is indistinguishable from that of normal oceanic crust. The Bay of Islands Ophiolite Complex is widely believed to represent a section of normal oceanic crust and upper mantle. However, some other 'ophiolitic' complexes in Newfoundland are thought to represent the foundation of island arc complexes, seamounts, and oceanic fracture zones [Williams and Talkington, 1977; Williams and Stevens, 1974; Karson and Dewey, 1978].

In the Blow-Me-Down massif the ultramafic rocks are dominantly harzburgitic; however, a considerable thickness of spinel lherzolite occurs at the base of the northernmost massif (Table Mountain). Both types clearly display tectonite fabrics thought to have developed by solid state deformation in the mantle. The tectonite fabric both cuts and is cut by numerous orthopyroxenite and dunite veins that probably crystallized from liquids trapped in the harzburgite during its ascent as a plastic mass from below a spreading center. The harzburgite is thought to represent depleted upper mantle peridotite produced by partial melting of lherzolite and subsequent removal of the basaltic liquid [Irvine and Findlay, 1972; Malpas, 1978]. The spinel therzolite may represent this source lherzolite or may be partially melted mantle material with incomplete liquid extraction. Overlying the harzburgites are dunites and feldspathic dunites with cumulate textures. Cumulate gabbros lie above the ultramafic rocks, and an interbanded zone of anorthosites, troctolites, and feldspathic dunites separates these two rock types. The gabbros are clearly enriched in cumulate plagioclase. The crystallization sequence of the gabbros is olivine followed by olivine + plagioclase and olivine + plagioclase + clinopyroxene. In the upper parts of the gabbro, late differentiates of trondhjemite occur. Dolerite dikes increase in quantity at the top of the gabbro, and higher up they become 'sheeted' (100\% dikes) and feed the overlying pillow lavas. The sheeted dike complex and the pillow lavas reach a total thickness of about $2.5 \mathrm{~km}$ where they are overlain by sediments. There is a rapid downward increase in metamorphic grade from zeolite through prehnite-pumpellyite to greenschist facies, suggesting ocean floor metamorphism under a high geothermal gradient [Einarson, 1975; Salisbury and Christensen, 1978].

\section{Samples}

Samples were collected by one of us (S.B.J.) during the summer of 1978 along the same general profile used by Salisbury and Christensen [1978]. Sample BOI-62B was obtained from N. Christensen. The Blow-Me-Down massif shows little evidence for postemplacement metamorphism, and good exposures with minimal weathering occur at all structural levels. Care was taken to obtain large samples free of weathering, but the alteration features characteristic of ophiolites could not be avoided. Above the pyroxene gabbro, all rocks are strongly altered to zeolite, greenschist, or amphibolite facies owing to preemplacement metamorphism, although relict igneous textures are common. Rocks with only minor alteration were found within the pyroxene and olivine gabbro units. The ultramafic rocks are serpentinized throughout the section, but care was taken to obtain samples with minimal serpentinization.

The stratigraphic position of the samples is shown in Figure 1. BMD-18A and BMD-3 are harzburgites where the primary assemblage appears to have been $77 \%$ olivine, $20 \%$ orthopyroxene, and $3 \%$ chrome spinel. About $50 \%$ of the olivine is 
altered to serpentine, and $\sim 50 \%$ of the orthopyroxene is altered to bastite. BMD-17 is a sample from a $10-\mathrm{cm}$-thick layer of 1- to 3-cm-sized orthopyroxene crystals which occurs between $\sim 10-\mathrm{cm}$-thick layers of dunite within the harzburgite. The cumulate gabbro samples BMD-2A, BOI-62B, and BMD-7 were selected for their freshness and preservation of primary magmatic minerals. They all have $\sim 50 \%$ plagioclase, $20-30 \%$ clinopyroxene, and variable amounts of olivine, brown and green primary hornblende, and rare orthopyroxene. BOI-62B is the only gabbro sample where orthopyroxene is a major phase ( 20\%). BMD-2A shows only very minor saussuritization of plagioclase and rare alteration of olivine to serpentine. BOI-62B and BMD-7 show minor saussuritization of plagioclase, some secondary amphibole, and minor alteration of olivine to serpentine. BMD-8 is a metagabbro with green hornblende, epidote, and plagioclase, and BMD-14 is a trondhjemite from the upper part of the metagabbro. Both samples have strongly saussuritized plagioclase. BMD-12A is from the sheeted dike complex and has $\sim 45 \%$ secondary green amphibole, $50 \%$ plagioclase, and $<1 \%$ of relict clinopyroxene. The plagioclase is brownish, cloudy, and saussuritized. Chlorite and blue-green amphibole also occur, but the relict subophitic texture shows the original dike rock was a dolerite. BMD-10 is a fine-grained greenschist facies metadolerite from the upper brecciated part of the sheeted dike complex. BMD-24 is a fine-grained pillowed metabasalt with a highly altered brownish groundmass with relict clinopyroxene and highly altered clinopyroxene and plagioclase phenocrysts. Zeolites and calcite occur in separate clusters in the groundmass and within amygdules.

\section{Experimental Procedures and Data REPRESENTATION}

Mineral separates were obtained magnetically and purified by handpicking. The plagioclase separates are better than $99 \%$ pure. The clinopyroxene separate for BMD-2A contains $\sim 20 \%$ plagioclase and $\sim 80 \%$ clinopyroxene due to the finescale intergrowth of plagioclase and pyroxene. For BMD-7 the clinopyroxene separate was free of plagioclase; however, it contains some primary green amphibole. Whole rock samples of $\sim 20 \mathrm{~g}$ were crushed, and 1- to $3-\mathrm{g}$ splits were dissolved in $\mathrm{HF}$ and $\mathrm{HClO}_{4}$. Sample BMD-18A had an insoluble residue of chrome spinel. Detailed descriptions of procedures are given by Papanastassiou and Wasserburg [1973] and by Papanastassiou et al. [1977]. Errors given for ${ }^{143} \mathrm{Nd} /{ }^{144} \mathrm{Nd}$ and ${ }^{87} \mathrm{Sr} /$ ${ }^{86} \mathrm{Sr}$ are $2 \sigma$ mean of $200-300$ ratios for $\mathrm{Nd}$ and $100-200$ ratios for $\mathrm{Sr}$. $\mathrm{K}, \mathrm{Ba}, \mathbf{R b}, \mathrm{Sr}, \mathrm{Sm}$, and Nd concentrations were obtained by isotope dilution techniques. Small $(<1 \%)$ aliquots of each sample were used to establish the approximate concentrations of these elements and the remaining solution was then spiked optimally to determine precise concentrations and isotopic compositions. Typically, an aliquot containing $\sim 100$ - to 200-mg sample was processed through the ion exchange columns a single time with a blank of $25 \mathrm{pg}$ for $\mathrm{Nd}$ and $100 \mathrm{pg}$ for Sr. For sample BMD-18A an aliquot containing $500 \mathrm{mg}$ of sample was split into two aliquots, which were separately passed through the first ion exchange column. The rare earth element (REE) fractions from these two aliquots were then together passed through the second column for separation of $\mathrm{Nd}$ and Sm. The estimated blank for this procedure is $50 \mathrm{pg}$ for Nd. For this sample a blank correction was made corresponding to $0.4 \varepsilon$ units for ${ }^{143} \mathrm{Nd} /{ }^{144} \mathrm{Nd}$ and $1.0 \%$ to the ${ }^{147} \mathrm{Sm} /{ }^{144} \mathrm{Nd}$ ratio.

Tables 1 and 3 summarize the analytical data. Excellent

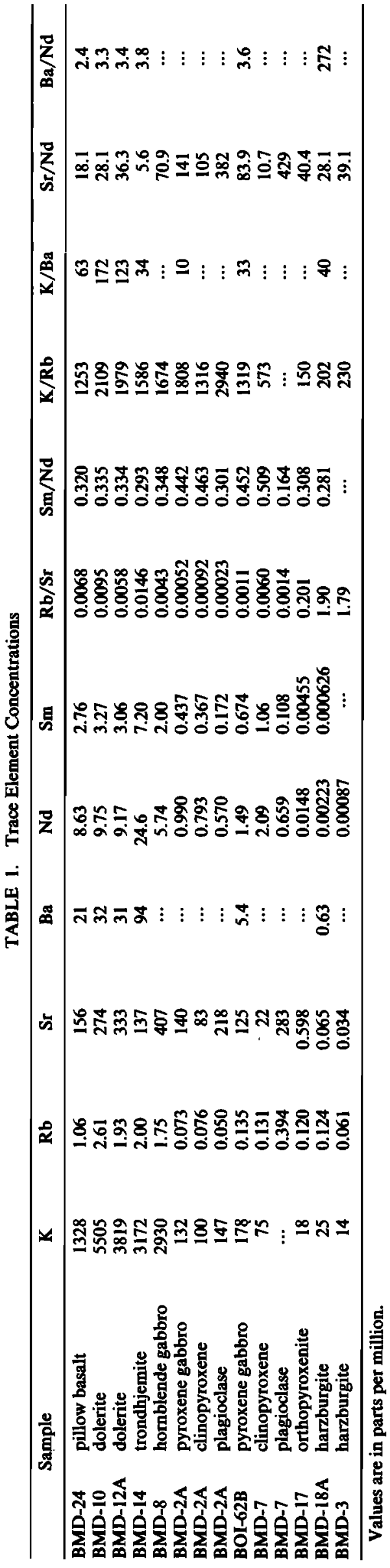




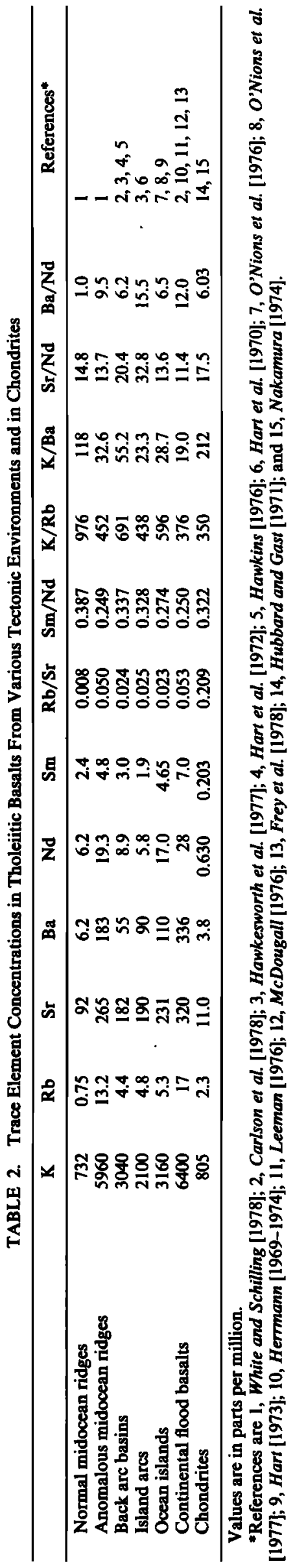

reproducibility is shown by repeat runs for BOI-62B and BMD-7 in Table 3. The nonradiogenic isotopes were measured in every experiment and found to be in excellent agreement with those of DePaolo and Wasserburg [1976a].

The initial ${ }^{143} \mathrm{Nd} /{ }^{144} \mathrm{Nd}$ and ${ }^{87} \mathrm{Sr} /{ }^{86} \mathrm{Sr}$ ratios of a rock of age $T$ are expressed as fractional deviations in parts in $10^{4}$ (called $\epsilon$ units) from the values in a uniform mantle reference reservoir at time $T$ and denoted by $\epsilon_{\mathrm{Nd}}$ and $\epsilon_{\mathrm{Sr}}$, respectively. The notation with $f$ and $\epsilon$ values follows that of DePaolo and Wasserburg [1976a, $b$, 1977]. The mantle reservoir used as a reference for the Sm-Nd system (CHUR) has a nominal chondritic $\mathrm{Sm} / \mathrm{Nd}$ ratio with $\left({ }^{147} \mathrm{Sm} /{ }^{144} \mathrm{Nd}\right)_{\mathrm{CHUR}}{ }^{0}=0.1936$ and ${ }^{143} \mathrm{Nd} /$ ${ }^{144} \mathrm{Nd}$ ratio today of $I_{\mathrm{CHUR}}{ }^{\mathrm{Nd}}(0)=0.511836$ [DePaolo and Wasserburg, 1976a]. The ratio ${ }^{143} \mathrm{Nd} /{ }^{144} \mathrm{Nd}$ in CHUR at any time $T$ in the past is given by

$$
I_{\text {CHUR }}{ }^{\mathrm{Nd}}(T)=I_{\text {CHUR }}{ }^{\mathrm{Nd}}(0)-\left(\frac{{ }^{147} \mathrm{Sm}}{{ }^{144} \mathrm{Nd}}\right)_{\mathrm{CHUR}}{ }^{0}\left(e^{\lambda \mathrm{sm}_{\mathrm{m}} r}-1\right)
$$

where $\lambda_{\mathrm{Sm}}=0.00654 \mathrm{aeon}^{-1}$. The reference reservoir for $\mathbf{R b}-\mathbf{S r}$ (UR) is taken to have $\left({ }^{87} \mathrm{Rb} /{ }^{86} \mathrm{Sr}\right) \mathrm{UR}^{0}=0.0827$, and the value of ${ }^{87} \mathrm{Sr} /{ }^{86} \mathrm{Sr}$ in UR at any time $\mathrm{T}$ in the past is given by

$$
I_{\mathrm{UR}}^{\mathrm{Sr}}(T)=I_{\mathrm{UR}}{ }^{\mathrm{Sr}}(0)-\left(\frac{{ }^{87} \mathrm{Rb}}{{ }^{86} \mathrm{Sr}}\right)_{\mathrm{UR}}{ }^{0}\left(e^{\lambda_{\mathrm{Rb}} T}-1\right)
$$

where $I_{\mathrm{UR}}{ }^{\mathrm{S}}(0)=0.7045$ is the value in UR today [DePaolo and Wasserburg, 1976b] and $\lambda_{\mathrm{Rb}}=0.0142$ aeon $^{-1}$. These reference reservoirs may be representative of the bulk earth.

The ${ }^{147} \mathrm{Sm} /{ }^{144} \mathrm{Nd}$ and ${ }^{87} \mathrm{Rb} /{ }^{86} \mathrm{Sr}$ ratios are expressed as enrichment factors in relation to CHUR and UR and are denoted $f^{\mathrm{Sm} / \mathrm{Nd}}$ and $f^{\mathrm{Rb} / \mathrm{S} \mathbf{r}}$, respectively, where

$$
\begin{aligned}
f^{\mathrm{Sm} / \mathrm{Nd}} & =\left[\frac{(\mathrm{Sm} / \mathrm{Nd})_{M}}{(\mathrm{Sm} / \mathrm{Nd})_{\mathrm{CHUR}}}-1\right] \\
f^{\mathrm{Rb} / \mathrm{Sr}} & =\left[\frac{(\mathbf{R b} / \mathrm{Sr})_{M}}{(\mathbf{R b} / \mathrm{Sr})_{\mathrm{UR}}}-1\right]
\end{aligned}
$$

and $M$ denotes the measured value. We emphasize the fact that the precise values for the bulk earth are not well known, although the estimates given above are widely used. However, it seems unlikely that the value of $I_{\mathrm{CHUR}}{ }^{\mathrm{Nd}}(0)$ which we are using is more than 2-3 $\epsilon$ units different from the true value [DePaolo and Wasserburg, 1976a, b]. This will not significantly alter the following discussion, although it might change substantial details of interpretation.

\section{DISCUSSION OF RESULTS FOR THE BAY OF ISLANDS COMPLEX}

\section{LIL Element Patterns}

From the major element chemistry it is clear that the Bay of Islands Ophiolite Complex is tholeiitic [Malpas, 1978]. It is therefore of interest to compare the trace element data for the Bay of Islands Ophiolite (Table 1) with those of a variety of oceanic and continental tholeiitic basalts (Table 2) to see whether these data indicate an oceanic affinity independent of inferences based on geologic structure or isotopic ratios. It has been known for over a decade that midocean ridge tholeiites have very distinctive large ion lithophile (LIL) element depleted patterns [Tatsumoto et al., 1965; Engel et al., 1965]. However, a recent study of incompatible element variations along the Mid-Atlantic ridge [White and Schilling, 1978] has shown that tholeiites from certain ridge segments are anoma- 
TABLE 3. Rb-Sr and Sm-Nd Isotopic Results

\begin{tabular}{lcccc}
\hline \multicolumn{1}{c}{ Sample* } & ${ }^{87} \mathrm{Rb} /{ }^{86} \mathrm{Sr} \dagger$ & ${ }^{87} \mathrm{Sr} /{ }^{86} \mathrm{Sr} \neq$ & ${ }^{147} \mathrm{Sm} /{ }^{144} \mathrm{Nd} 8$ & ${ }^{143} \mathrm{Nd} /{ }^{144} \mathrm{Nd} \|$ \\
\hline BMD-24-TR & 0.01964 & $0.70448 \pm 2$ & 0.19329 & $0.512222 \pm 16$ \\
BMD-10-TR & 0.02754 & $0.70519 \pm 3$ & 0.20301 & $0.512283 \pm 25$ \\
BMD-12A-TR & 0.01678 & $0.70523 \pm 2$ & 0.20212 & $0.512277 \pm 25$ \\
BMD-14-TR & 0.04224 & $0.70649 \pm 4$ & 0.17763 & $0.512142 \pm 26$ \\
BMD-8-TR & 0.01243 & $0.70561 \pm 3$ & 0.21014 & $0.512284 \pm 25$ \\
BMD-2A-TR & $\ldots$ & $\ldots$ & 0.21014 & $0.512258 \pm 13$ \\
BMD-2A-CPX & 0.001511 & $0.70254 \pm 5$ & 0.26722 & $0.512472 \pm 28$ \\
BMD-2A-PLAG & 0.002670 & $0.70258 \pm 4$ & 0.27995 & $0.512516 \pm 15$ \\
BOI-62B-TR-A & 0.000666 & $0.70255 \pm 2$ & 0.18236 & $0.512191 \pm 34$ \\
BOI-62B-TR-B & 0.003029 & $0.70317 \pm 4$ & 0.27363 & $0.512435 \pm 20$ \\
BMD-7-CPX & $\ldots$ & $\ldots$ & 0.27363 & $0.512433 \pm 14$ \\
BMD-7-PLAG & $\ldots .$. & $\ldots$ & 0.27340 & $0.512445 \pm 24$ \\
BMD-17-TR & 0.01720 & $0.70285 \pm 3$ & 0.30765 & $0.512588 \pm 23$ \\
BMD-18A-TR & 0.004035 & $0.70275 \pm 2$ & 0.30765 & $0.512594 \pm 33$ \\
\hline
\end{tabular}

*TR is total rock, CPX is clinopyroxene, PLAG is plagioclase, and OPX is orthopyroxene.

†Uncertainty, $\pm 1.0 \%$.

$\ddagger$ Normalized to ${ }^{86} \mathrm{Sr} /{ }^{88} \mathrm{Sr}=0.1194$; errors are $2 \sigma$ mean.

\$Maximum uncertainty, $\pm 0.1 \%$.

||Normalized to ${ }^{146} \mathrm{Nd} /{ }^{142} \mathrm{Nd}=0.636151$; errors are $2 \sigma$ mean.

lous in that they show strong LIL element enrichment and resemble tholeiites from oceanic islands or continents. These occurrences are presumably rare, and it is reasonable to assume that the LIL-depleted patterns are characteristic of the predominant oceanic tholeiites. The extent to which this trace element chemistry is characteristic throughout geologic time remains a fundamental question. The pillow basalt BMD-24 has concentration levels and a $K / R b$ ratio that compare well with normal midocean ridge tholeiites; however, its $\mathrm{K} / \mathrm{Ba}$ ratio is lower than that of typical MORB. The dolerite samples BMD-10 and BMD-12A have somewhat higher concentrations and high $\mathrm{K} / \mathrm{Ba}$ ratios typical of MORB. Alteration of ocean floor basalts generally leads to an increase in the concentration of $\mathrm{K}, \mathrm{Rb}$, and $\mathrm{Ba}$ and the $\mathrm{K} / \mathrm{Ba}$ ratio [Hart et al., 1974]. Therefore even considering the altered nature of these samples, we conclude that they show an affinity with normal midocean ridge tholeiites. The LIL element patterns also are distinctly different from those of oceanic island, island arc, and continental tholeites but similar to those of tholeiites from marginal basins.

Rare earth patterns from the Bay of Islands Complex have been reported by Malpas [1978], and our Sm and Nd concentrations and the implied fractionation patterns are compatible with these. There is a clear similarity of the REE pattern of the pillow lavas with the light rare earth element (LREE)-depleted patterns of normal midocean ridge basalts. The dolerites have a somewhat lower REE abundance and stronger LREE depletion than the pillow lavas. The gabbros have very low $R b$ and REE concentrations and show strong LREE depletion and positive Eu anomalies. This is consistent with the interpretation that they are plagioclase-enriched cumulates.

Analyses of other ophiolites show the same pattern of REE, $\mathrm{K}, \mathrm{Rb}, \mathrm{Sr}$, and $\mathrm{Ba}$ contents [Allègre et al., 1973; Montigny et al., 1973; Kay and Senechal, 1976] for basalts, dolerites, and gabbros as those of the Bay of Islands Complex. Allègre et al. [1973] have shown that these typical REE patterns for the pillow lavas, dolerites, and cumulate gabbros of ophiolites can be modeled by closed system fractional crystallization using the observed cumulate assemblages in the gabbros.

The harzburgites show extremely low contents of in- compatible elements (Table 1). The concentrations of Nd and Sm are a factor of $\sim 500$ lower than chondritic abundances and a factor of $\sim 10^{4}$ lower than in the dolerites and basalts. These low concentrations support the hypothesis that the harzburgite is the residual mantle remaining after extraction of midocean ridge basalt magmas, although owing to the serpentinized nature of these samples, details of the interpretation are not clear. Available data on harzburgites from other ophiolites show that they also have very low REE concentrations [Allègre et al., 1973; Montigny et al., 1973; Kay and Senechal, 1976]. However, their Sm and Nd concentrations are lower by only a factor of $\sim 300$ in relation to overlying basalts and dolerites. In all cases, however, very efficient extraction of LIL elements from the source of midocean ridge basalts is indicated.

For the interpretation of $\mathrm{Nd}$ and $\mathrm{Sr}$ isotopic data on midocean ridge (MOR) basalts and ophiolites it is of importance to have good estimates of $f^{\mathrm{Rb} / \mathrm{sr}}$ and $f^{\mathrm{Sm} / \mathrm{Nd}}$ in their sources. The average values for the oceanic crust may presumably be taken as the average value for the present-day MORB source. The average of individual ophiolites may be taken as estimates for their sources. This should be a good approximation, since the harzburgite residue left in the mantle after production of MOR tholeiite magmas contains insignificant amounts of LIL elements as discussed above. Oceanic gabbros and ophiolitic gabbros give an average $f^{\mathrm{Rb} / \mathrm{Sr}}=-0.95 \pm 0.05$ [Kay et al., 1970; Spooner et al., 1977] (see Table 4). The average value for unaltered normal MORB is $f^{\mathrm{Rb} / \mathrm{Sr}}=-0.8 \pm 0.1$. The average $\mathrm{Sr}$ concentration is about $100 \mathrm{ppm}$ in both the upper (basalt and dolerite) and the lower (gabbro) oceanic crust, which as a final result gives an average value for oceanic crust of $f^{\mathrm{Rb} / \mathrm{Sr}}=-0.9_{-0.05}^{+0}$. From the data in Table 4 this $f$ value also seems to apply to the Bay of Islands Complex. The average of 30 normal MORB gives $f^{\mathrm{sm} / \mathrm{Nd}}=+0.12$ and $\mathrm{Nd}=6.5$ ppm [Kay et al., 1970; O'Nions et al., 1977; Carlson et al., 1978], and the average of 6 oceanic gabbros [Masuda and Jibiki, 1973; Kay et al., 1970] gives $f^{\mathrm{sm} / \mathrm{Nd}}=+0.42$ and $\mathrm{Nd}=3.3$ ppm. Similar estimates are indicated from data on ophiolites [Montigny et al., 1973; Kay and Senechal, 1976]. The average for the Bay of Islands Complex appears to be $f^{\mathrm{sm} / \mathrm{Nd}} \approx+0.2$ 


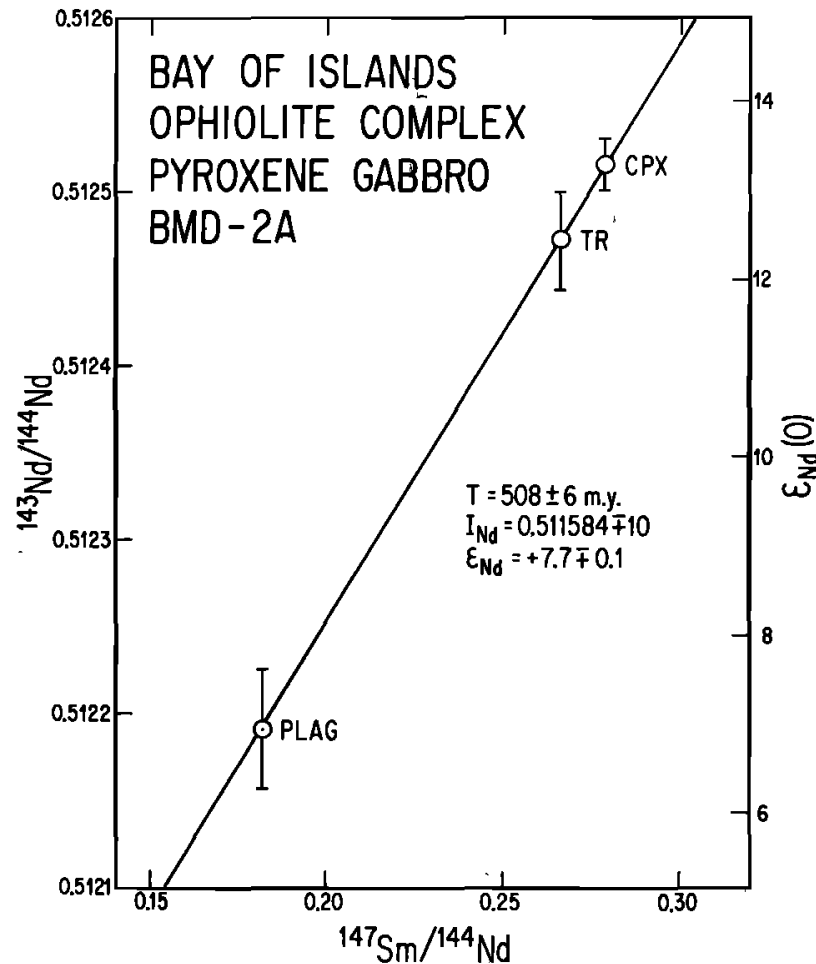

Fig. 2. Sm-Nd evolution diagram showing the mineral isochron determined for the pyroxene gabbro sample BMD-2A.

from the data in Table 4 and the REE patterns of Malpas [1978]. Assuming that the lower half of the oceanic crust is made of gabbro, this gives $f^{\mathrm{Sm} / \mathrm{Nd}}=+0.22$ and $(\mathrm{Sr} / \mathrm{Nd}) \approx 22$ for the average oceanic crust.

\section{Age and Initial $\mathrm{Nd}$ and $\mathrm{Sr}$}

We have attempted to determine the crystallization age using the ${ }^{147} \mathrm{Sm}-{ }^{143} \mathrm{Nd}$ method on two unaltered gabbro samples BMD-2A and BMD-7. The difficulty of obtaining precise dates on old terrestrial mafic and ultramafic rocks is well known. Other methods (K-Ar, Rb-Sr, U-Th-Pb) are much more susceptible to element redistribution subsequent to the time of crystallization and in many cases give a metamorphic age or intermediate ages of doubtful meaning rather than the time of crystallization. Using these methods, it is often necessary to use minor phases and/or associated differentiated rocks whose relationship to the mafic/ultramafic rocks is difficult to establish unequivocally. However, with the Sm-Nd method it is possible to determine directly the crystallization age of major mafic/ultramafic igneous rocks. Sufficiently large differences in $\mathrm{Sm} / \mathrm{Nd}$ ratios exist between plagioclase and pyroxene, which are the most common phases in gabbroic rocks, such that the Sm-Nd system can be used to obtain precise ages for most gabbroic rocks. The success of this approach has been shown for anhydrous systems in meteoritic and lunar basic rocks [Lugmair, 1974; Lugmair et al., 1976; Papanastassiou et al., 1977] and in a hydrous environment in a terrestrial gabbro [DePaolo and Wasserburg, 1979b]. A successful total rock approach has been reported by Hamilton et al. [1977].

The Sm-Nd data for BMD-2A are given in Table 3 and Figure 2. The plagioclase separate shows ${ }^{147} \mathrm{Sm} /{ }^{144} \mathrm{Nd} \simeq 0.18$, much lower than that of the total rock $(0.27)$. The pyroxene separate contained $20 \%$ plagioclase and therefore has an $\mathrm{Sm}$ / Nd ratio only slightly higher than the total rock. The data de- fine an age of $508 \pm 6 \mathrm{~m} . \mathrm{y}$. and initial ${ }^{143} \mathrm{Nd} /{ }^{144} \mathrm{Nd}$ of $\epsilon_{\mathrm{Nd}}=$ $+7.7 \mp 0.1$ but only show a relatively small range in ${ }^{143} \mathrm{Nd} /$ ${ }^{144} \mathrm{Nd}$ of $\sim 6 \epsilon$ units. The small uncertainty given by a York [1966] fit is due to the fact that the three data points are centered on the isochron to within $0.1 \epsilon$ units. The total rock points have higher concentration of $\mathrm{Nd}$ than both the pyroxene and plagioclase, so it seems unlikely that the line is a twocomponent mixing line. To confirm this age, we analyzed a second pyroxene gabbro. The Sm-Nd data on BMD-7 are shown in Table 3 and Figure 3. The plagioclase and the pyroxene show a much larger spread in ${ }^{147} \mathrm{Sm} /{ }^{144} \mathrm{Nd}(0.099$ 0.31) than that of BMD-2A. BMD-7 yields an age of $501 \pm 13$ m.y. and an initiall $\epsilon_{\mathrm{Nd}}=7.5 \mp 0.2$. The uncertainties represent our best estimates and correspond to the maximum change in the slope of the isochron allowed by the $1 \sigma$ uncertainties of the duplicate analyses of both data points. The large range of $\sim 14 \epsilon$ units permits this precise age determination. The concordant $\mathrm{Sm} / \mathrm{Nd}$ ages for the two pyroxene gabbros strongly indicate that this is the time of crystallization. Insofar as the mobility of Sm and Nd during metamorphism and weathering is negligible, and since the data were obtained on primary magmatic phases, these ages are interpreted to be the crystallization age of the gabbro at the time of its emplacement in the oceanic crust. A nominal age of $505 \mathrm{~m} . \mathrm{y}$. is assigned to both samples. We have relied on an internal isochron, since ages obtained by total rock isochrons depend on the assumption that all the rocks had the same initial isotopic composition and age. This would not be expected to be a problem for minerals from a single total rock sample. The internal isochron has the disadvantage that later metamorphism is more likely to cause isotopic equilibration on the scale of minerals than on the scale of total rocks. We therefore also compare data from several other total rock samples with the internal isochron (Table 3 and Figure 4). One two-pyroxene gabbro plots off the isochron by $\sim 1.1 \epsilon$ units and must represent a distinctly different age or initial value. The other samples plot on the mineral isochron. The harzburgite BMD-18A is compatible with the mineral isochron, but the ${ }^{143} \mathrm{Nd} /{ }^{144} \mathrm{Nd}$ ratio is much less precise, since it was measured on $1 \mathrm{ng}$ of $\mathrm{Nd}$ and no firm conclusion can be drawn other than that it is not grossly aberrant.

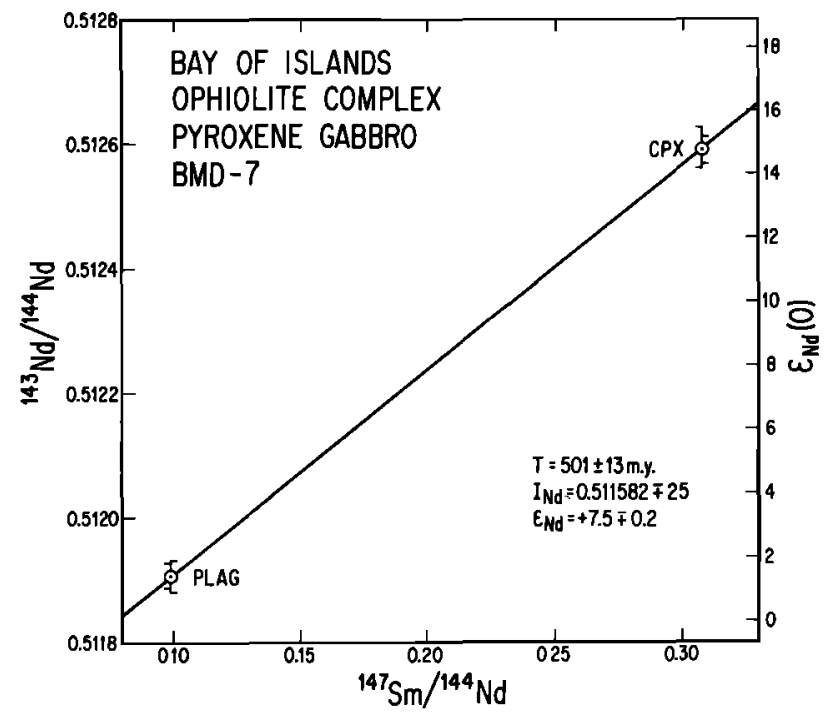

Fig. 3. Sm-Nd evolution diagram showing the mineral isochron determined for the pyroxene gabbro sample BMD-7. 
TABLE 4. Evolutionary Parameters for Nd and Sr

\begin{tabular}{|c|c|c|c|c|}
\hline Sample* & $f^{\mathbf{R b} / \mathbf{S}_{\mathbf{r}}}$ & $\varepsilon_{\mathrm{Sr}}$ & $f^{\mathrm{Sm} / \mathrm{Nd}}$ & $\boldsymbol{E}_{\mathbf{N d}}$ \\
\hline BMD-24-TR & -0.7625 & $\begin{array}{c}\text { Pillow Lavas } \\
+6.2 \pm 0.3\end{array}$ & -0.0016 & $+7.6 \pm 0.3$ \\
\hline $\begin{array}{l}\text { BMD-!0-TR } \\
\text { BMD-12A-TR }\end{array}$ & $\begin{array}{l}-0.6670 \\
-0.7971\end{array}$ & $\begin{array}{l}\text { Sheeted Dikes } \\
+15.4 \pm 0.4 \\
+17.1 \pm 0.3\end{array}$ & $\begin{array}{l}+0.0486 \\
+0.0440\end{array}$ & $\begin{array}{l}+8.1 \pm 0.5 \\
+8.1 \pm 0.5\end{array}$ \\
\hline BMD-14 & -0.4892 & $\begin{array}{l}\text { Trondhjemite } \\
+32.5 \pm 0.6\end{array}$ & -0.0825 & $+7.0 \pm 0.5$ \\
\hline BMD-8 & $\begin{array}{c}-0.8497 \\
\ldots\end{array}$ & $\begin{array}{c}\text { Gabbros } \\
+23.0 \pm 0.4 \\
\ldots\end{array}$ & $\begin{array}{c}+0.0854 \\
\ldots\end{array}$ & $\begin{array}{l}+7.7 \pm 0.5 \\
+7.2 \pm 0.3\end{array}$ \\
\hline $\begin{array}{l}\text { BMD-2A-TR } \\
\text { BMD-2A-CPX } \\
\text { BMD-2A-PLAG } \\
\text { BOI-62B-TR-A }\end{array}$ & $\begin{array}{c}-0.9817 \\
-0.9677 \\
-0.9919 \\
-0.9634 \\
\ldots\end{array}$ & $\begin{array}{c}-19.6 \pm 0.7 \\
-19.1 \pm 0.6 \\
-19.3 \pm 0.3 \\
-10.7 \pm 0.6 \\
\ldots .\end{array}$ & $\begin{array}{c}+0.3803 \\
+0.4460 \\
-0.0581 \\
+0.4134 \\
\ldots\end{array}$ & $\begin{array}{l}+7.7 \pm 0.6 \\
+7.7 \pm 0.3 \\
+7.7 \pm 0.7 \\
+6.5 \pm 0.4 \\
+6.5 \pm 0.3\end{array}$ \\
\hline $\begin{array}{l}\text { BOI-62B-TR-B } \\
\text { BMD-7-CPX }\end{array}$ & $\begin{array}{c}\ldots \\
-0.7920 \\
\ldots\end{array}$ & $\begin{array}{c}\cdots \\
-16.7 \pm 0.4 \\
\ldots\end{array}$ & $\begin{array}{l}+0.4122 \\
+0.5891 \\
\ldots\end{array}$ & $\begin{array}{l}+6.7 \pm 0.5 \\
+7.3 \pm 0.4 \\
+7.4 \pm 0.6\end{array}$ \\
\hline BMD-7-PLAG & $\begin{array}{c}-0.9512 \\
\cdots\end{array}$ & $\begin{array}{c}-16.8 \pm 0.3 \\
\cdots\end{array}$ & $\begin{array}{c}-0.4879 \\
\cdots\end{array}$ & $\begin{array}{l}+7.5 \pm 0.5 \\
+7.5 \pm 0.4\end{array}$ \\
\hline $\begin{array}{l}\text { BMD-17-TR } \\
\text { BMD-18A-TR }\end{array}$ & $\begin{array}{r}+6.057 \\
+65.32\end{array}$ & $\begin{array}{c}\text { Harzburgite } \\
-0.9 \pm 0.6 \\
-171.6 \pm 16.0\end{array}$ & $\begin{array}{l}-0.0365 \\
-0.1333\end{array}$ & $\begin{array}{l}+7.4 \pm 0.8 \\
+3.2 \pm 11.7\end{array}$ \\
\hline
\end{tabular}

$\varepsilon$ values calculated for an age of 505 m.y.

*See Table 3 footnotes.

The $\epsilon_{\mathrm{Nd}}$ values for all samples are given for a nominal age of 505 m.y. in Table 4. We obtain initial $\epsilon_{\mathrm{Nd}}$ in the range from +7.0 to +8.1 for metagabbro, trondhjemite, and metadolerite samples. The pillow basalt sample has a ${ }^{147} \mathrm{Sm} /{ }^{144} \mathrm{Nd}$ ratio which is very near to chondritic, so the initial value for this sample relative to the CHUR evolution line can be established as $\epsilon_{\mathrm{Nd}}=+7.6 \pm 0.3$, essentially independent of its age. The orthopyroxenite layer (BMD-17) from the harzburgite has a similar value of $\epsilon_{\mathrm{Nd}}=+7.4 \pm 0.8$. This indicates that the harzburgite is cogenetic with the remaining part of the ophiolite and supports the hypothesis that the harzburgite represents residual mantle remaining from the partial melting which produced the rest of the ophiolite. If we assume the same age for BOI-62B, we obtain a distinctly lower initial value of $\epsilon_{\mathrm{Nd}}=$ $+6.5 \pm 0.4$. The observed inhomogeneity in initial $\mathrm{Nd}$ in this complex obviously makes precise age determinations by whole rock measurements difficult. Although field and petrologic evidence may suggest that all the samples appear to be differentiation products of the same magma, the data require that the parent magma was isotopically inhomogeneous owing to contamination or that the complex is the result of multiple injection from mantle sources with variable Nd isotopic composition. The total rock Sm-Nd method has been used to obtain ages often over a broad geologic scale and including distinctive lithic units [Hamilton et al., 1977, 1978, 1979; Zindler et al., 1978], although it is evident that the assumption of uniform initial isotopic composition does not apply even within a single profile through a well-defined complex as the Bay of Islands. Some caution using this approach may be necessary.

The Rb-Sr data are also shown in Table 3, and the $\epsilon_{\mathrm{sr}}$ values are given for a nominal age of $505 \mathrm{~m} . \mathrm{y}$. in Table 4 . The data for the gabbros, dolerites, and pillow basalts are shown in Figure 5. They all have very low ${ }^{87} \mathrm{Rb} /{ }^{86} \mathrm{Sr}$ ratios $(<0.02)$ and would not have changed their ${ }^{87} \mathrm{Sr} /{ }^{86} \mathrm{Sr}$ due to in situ decay of ${ }^{87} \mathrm{Rb}$ by any substantial amount. It is clear that the different total rock samples show a wide scatter on the $\mathbf{R b}-\mathbf{S r}$ evolution diagram. Samples of minerals and total rock from the fresh gabbro BMD-2A give measured ${ }^{87} \mathrm{Sr} /{ }^{86} \mathrm{Sr}$ ratios which are all the same within error. The clinopyroxene has the highest ${ }^{87} \mathrm{Rb} /{ }^{86} \mathrm{Sr}$ ratio of 0.0027 . The total evolution in ${ }^{87} \mathrm{Sr} /{ }^{86} \mathrm{Sr}$ for this phase in $505 \mathrm{~m} . \mathrm{y}$. is $0.3 \epsilon$ units, so an estimate

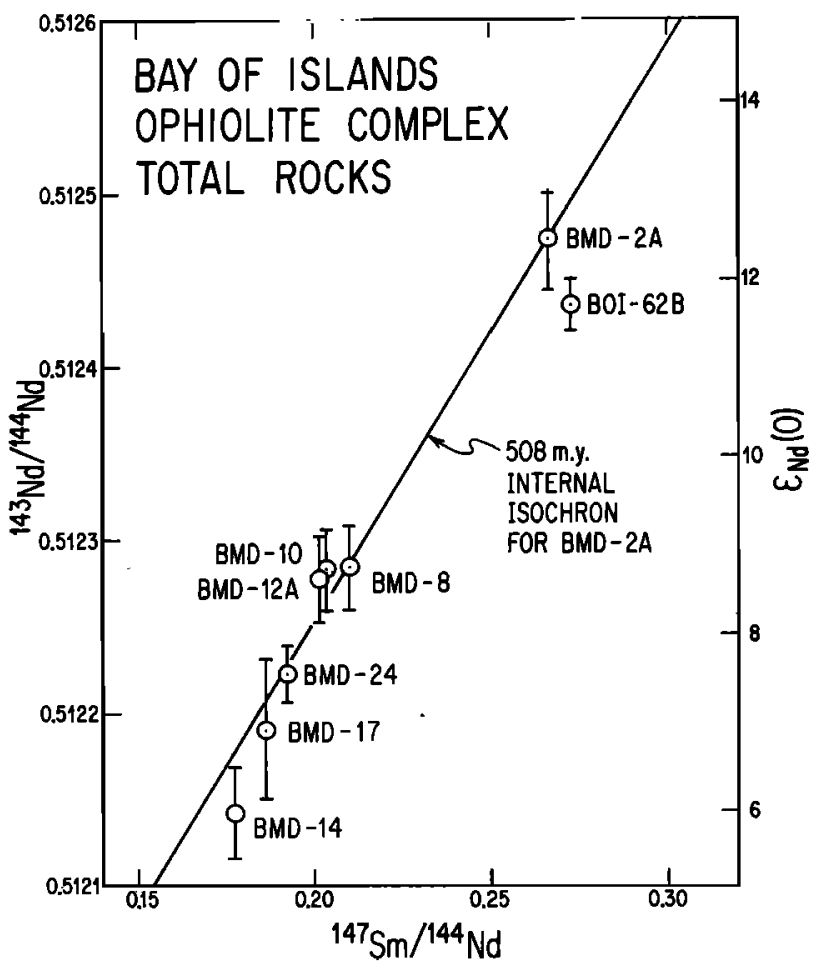

Fig. 4. Sm-Nd evolution diagram showing the data for whole rock samples of pillow basalt, sheeted dikes, trondhjemite, gabbros, and an orthopyroxenite layer in the harzburgite. The 508-m.y. mineral isochron for BMD-2A is shown for reference. All the data do not fit the isochron. Note that BOI-62B does not lie on the mineral isochron and indicates a distinctive initial value. The data point for the orthopyroxenite BMD-17 indicates that the harzburgite is cogenetic with the upper mafic part of the ophiolite. 


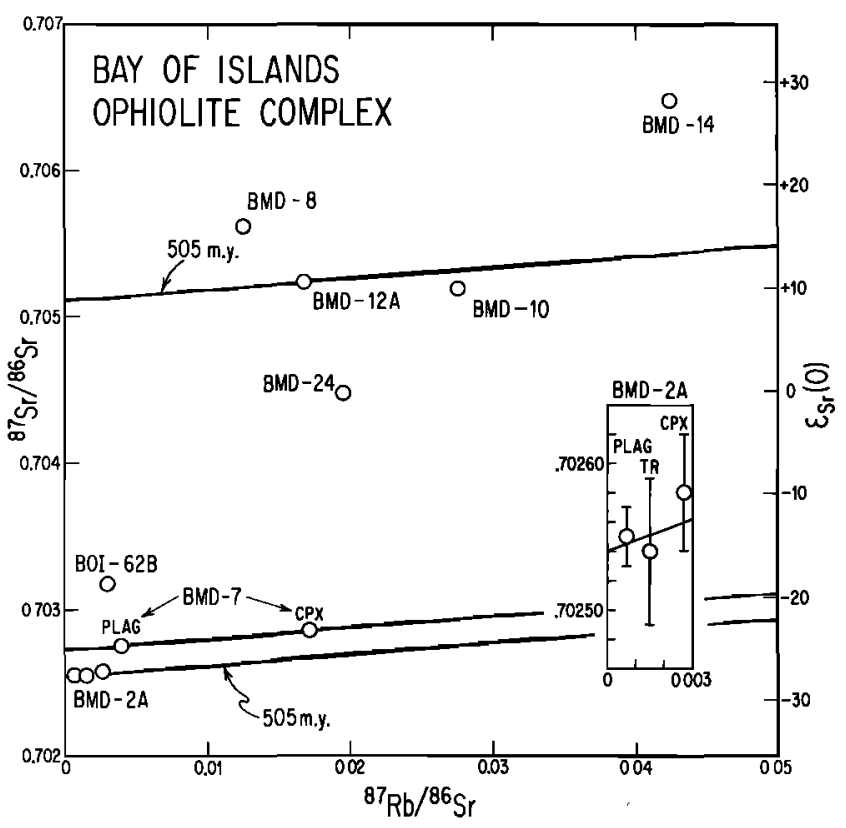

Fig. 5. Rb-Sr evolution diagram showing the mineral and total rock data for samples from the Blow-Me-Down massif. Reference lines with slopes corresponding to the $\mathrm{Sm} / \mathrm{Nd}$ age are shown. Note the wide range in initial ${ }^{87} \mathrm{Sr} /{ }^{86} \mathrm{Sr}$ for different samples and the implied range in initial strontium.

of the age cannot be obtained from these data. The initial ${ }^{87} \mathrm{Sr} /{ }^{86} \mathrm{Sr}$ value is $0.70254 \pm 2$, or $\epsilon_{\mathrm{sr}}=-19.3 \pm 0.3$. For BMD-7 both clinopyroxene and plagioclase give the same initial ${ }^{87} \mathrm{Sr} /{ }^{86} \mathrm{Sr}$ ratios of $0.70272 \pm 2$, or $\epsilon_{\mathrm{Sr}}=-16.8 \pm 0.3$. Since the minerals would have different susceptibilities to Sr migration and have the same $\epsilon_{\mathrm{Sr}}$, this is good evidence that we are measuring the $\mathrm{Sr}$ isotope composition of these rocks at the time of crystallization. The two-pyroxene gabbro BOI-62B also has a very low ${ }^{87} \mathrm{Rb} /{ }^{86} \mathrm{Sr}$ ratio of $\sim 0.003$ and gives an initial ${ }^{87} \mathrm{Sr} /$ ${ }^{86} \mathrm{Sr}$ of $0.70315 \pm 4$. This is higher than that of BMD-2A and BMD-7, and since the sample shows only minor signs of alteration, we take this to indicate a significantly different initial $\mathbf{S r}$ value from the two other samples. The difference in ${ }^{87} \mathrm{Sr} /{ }^{86} \mathrm{Sr}$ cannot be due to an age difference. It appears that the three pyroxene gabbros show significant differences in initial Sr. BOI-62B also shows a significantly different initial $\mathrm{Nd}$ from those of BMD-7 and BMD-2A.

Sr analyses were carried out also on samples of metagabbro, trondhjemite, metadolerite, and pillow basalt which had obviously been subject to hydrothermal metamorphism. These samples give a wide spread in $\epsilon_{\mathrm{Sr}}$ from +6.2 to +32.5 , which is very different from the tightly clustered $\epsilon_{\mathrm{Nd}}$ data. We note that the $\epsilon_{\mathrm{S}}$ values in general show an increase with the degree of metamorphism and alteration. This further demonstrates the much larger mobility of Rb-Sr compared to Sm and Nd during hydrothermal and metamorphic processes, as has been evident from previous studies. This is most likely due to the lower solubility of REE in aqueous solutions and the difference in diffusivity in the solid phases, as compared to Rb-Sr.

The harzburgite BMD-18A has both a high ${ }^{87} \mathrm{Rb} /{ }^{86} \mathrm{Sr}$ ratio and ${ }^{87} \mathrm{Sr} /{ }^{86} \mathrm{Sr}$ ratio for an ultramafic rock (Table 3). The ${ }^{87} \mathrm{Sr} /$ ${ }^{86} \mathrm{Sr}$ ratio for this sample is less precise than for other samples, since it was measured on only $20 \mathrm{ng}$ of Sr. It yields a $T_{\mathrm{BABI}}$ model age of $414 \pm 6 \mathrm{~m}$.y., and, following the discussion of $T_{\text {BABl }}$ model ages by Wasserburg and Papanastassiou [1975], this demonstrates that this sample has been disturbed sub- sequent to this time. $\mathrm{Rb}-\mathrm{Sr}$ data for harzburgites from alpine peridotites and ophiolites by other workers show that primary minerals have much lower $\mathrm{Rb} / \mathrm{Sr}$ ratios [Menzies and Murthy, [1978] and that secondary phases often have high $\mathrm{Rb} / \mathrm{Sr}$ ratios [Brueckner, 1975]. The high $\mathrm{Rb} / \mathrm{Sr}$ ratio measured in BMD-18A may thus be related to serpentinization of the sample. The serpentinization of harzburgites in ophiolites is known to occur after their emplacement on the continents [Wenner and Taylor, 1973], so the younger age is plausible. The relatively fresh orthopyroxenite BMD-17 also has a relatively high $\mathrm{Rb} / \mathrm{Sr}$ ratio, but it is only one tenth of that in the harzburgite.

\section{Strontium Isotope Contamination}

Isotopic studies of ocean floor basalts and of the Troodos ophiolite have clearly demonstrated that ${ }^{87} \mathrm{Sr} /{ }^{86} \mathrm{Sr}$ in altered samples generally has been increased owing to interaction with seawater [Dasch et al., 1973; Hart et al., 1974; Spooner et al., 1977]. Changes in ${ }^{87} \mathrm{Sr} /{ }^{86} \mathrm{Sr}$ by seawater interaction have, however, not been observed to be accompanied by significant changes in ${ }^{143} \mathrm{Nd} /{ }^{144} \mathrm{Nd}$ ratios [O'Nions et al., 1977, 1978a]. Present-day oceans appear to be large, well-mixed reservoirs of $\mathrm{Sr}$ with ${ }^{87} \mathrm{Sr} /{ }^{86} \mathrm{Sr}=0.7091 \pm 1$, or $\epsilon_{\mathrm{sr}}(0)=+65.3 \pm 1.4$ [Papanastassiou et al., 1970; Hildreth and Henderson, 1971], and a Sr concentration of $7.9 \mathrm{ppm}$ [Holland, 1978] and are thus isotopically distinct from oceanic basalts. The ${ }^{143} \mathrm{Nd} /$ ${ }^{144} \mathrm{Nd}$ ratio in seawater show a large range from $\epsilon_{\mathrm{Nd}}(0)=-1$ to -14 [DePaolo and Wasserburg, 1977; O'Nions et al., 1978a; Piepgras et al., 1979], which is also distinct from oceanic basalt values. The concentration of $\mathrm{Nd}$ in seawater is only $3 \times 10^{-6}$ ppm [Hogdahl et al., 1968] and is the reason why changes in ${ }^{143} \mathrm{Nd} /{ }^{144} \mathrm{Nd}$ ratios have not been observed in altered ocean floor basalts.

Rocks from the Bay of Islands ophiolite have a range of 1.6 $\epsilon$ units in initial $\mathrm{Nd}$, while the initial $\epsilon_{\mathrm{sr}}$ values show a range of $52 \epsilon$ units. The initial magmatic ${ }^{87} \mathrm{Sr} /{ }^{86} \mathrm{Sr}$ is in the range $\epsilon_{\mathrm{Sr}_{\mathrm{r}}}=$ -19.3 to -10.7 on fresh gabbro samples. Higher $\epsilon_{\mathrm{Sr}}$ values are associated with hydrothermally metamorphosed samples. Since there is a general increase in the $\epsilon_{\mathrm{Sr}}$ value with the degree of alteration, we attribute these higher values to contamination by seawater. The magnitude of the $\epsilon_{\mathrm{Sr}}$ shifts is similar to that observed in the much younger Troodos ophiolite [Spooner et al., 1977].

The amount of seawater needed for the observed $\epsilon_{\mathrm{Sr}}$ shift may be calculated. The volumetric water/rock ratio $(=W / R)$ is given by

$$
\frac{W}{R}=\frac{\epsilon_{\mathrm{Sr}}-\epsilon_{\mathrm{Sr}}{ }^{B}}{\epsilon_{\mathrm{Sr}_{\mathrm{r}}}{ }^{2}-\epsilon_{\mathrm{Sr}}} \frac{\mathrm{Sr}_{B}}{\mathrm{Sr}_{S W}} \rho
$$

where $B$ denotes the unaltered sample and $S W$ denotes seawater. We use $\epsilon_{\mathrm{Sr}_{\mathrm{r}}}{ }^{B}=-19.3$ and $\epsilon_{\mathrm{S}_{\mathrm{r}}}{ }^{s W}=+72$ (estimated for Cambrian seawater; [Veizer and Compston, 1974]) and $\rho \simeq 3$ $\mathrm{g} / \mathrm{cm}^{3}$. This model assumes $100 \%$ efficiency in $\mathrm{Sr}$ exchange and therefore gives a minimum water/rock ratio. The bulk seawater rock ratio for the metagabbro is thus at least $\sim 130: 1$ and for the pillow basalt at least $\sim 23: 1$.

Using the above mentioned parameters for $\mathrm{Sr}$ and assuming that Cambrian seawater has $\epsilon_{\mathrm{Nd}}=-5$, we can calculate the mixing curve between an uncontaminated rock $(\mathrm{Nd}=8 \mathrm{ppm}$ and $\mathrm{Sr}=120 \mathrm{ppm}$ ) and seawater. The shape of the mixing curve depends on the parameter $K_{\mathrm{Sr} / \mathrm{Nd}}{ }^{R-W}=(\mathrm{Sr} / \mathrm{Nd})_{\text {rock }} /(\mathrm{Sr} /$ $\mathrm{Nd})_{\text {seawater }}=5.7 \times 10^{-6}$. The mixing line in the $\epsilon_{\mathrm{Nd}}-\epsilon_{\mathrm{Sr}}$ diagram is horizontal almost until it reaches the seawater value for $\epsilon_{\mathrm{Sr}}$ 




Fig. 6. Histogram comparing initial $\varepsilon_{\mathrm{Nd}}$ values from the Bay of Islands Complex with values for young basalts. Data are from DePaolo and Wasserburg [1976a, b, 1977], Richard et al. [1976], O'Nions et al. [1977], Hawkesworth et al. [1977], and Carlson et al. [1978]. The Bay of Islands Complex clearly has an oceanic affinity. The average value $(+7.6)$ is, however, somewhat smaller than the average value of MORB $(+10)$. This is most likely due to differential evolution of the oceanic mantle relative to the bulk earth over the past 0.5 aeon.

(Figure 7). The water/rock ratios shown on the mixing line in Figure 7 assume $100 \%$ efficiency of exchange for $\mathrm{Nd}$ and $\mathrm{Sr}$. In this case the $\epsilon_{\mathrm{Nd}}$ value cannot change significantly before the water/rock ratio is $\sim 10^{5}$.

Oxygen and $\mathrm{Sr}$ isotope data and $\mathrm{Fe}_{2} \mathrm{O}_{3} / \mathrm{FeO}^{*}$ ratios together with other geological evidence strongly suggest that the pervasive hydrothermal metamorphism observed in the pillow lavas and sheeted dikes of ophiolites occurred in a sub-seafloor geothermal system at a spreading center [Spooner et al., 1974, 1977]. The Bay of Islands data indicate that similar geothermal systems may have been active in Cambrian ocean ridges. The upper oceanic crust (pillow lavas and sheeted dikes) seems to have been a sink for $\mathrm{Sr}$ from seawater throughout the Phanerozoic. This can result in recycling of continental $\mathrm{Sr}$ into the mantle in subducted oceanic slabs. Nd and $\mathrm{Sr}$ isotopic studies of some young island arc tholeiites and dacites [DePaolo and Wasserburg, 1977; Hawkesworth et al., 1977] suggest that they may be derived from altered oceanic crust, since they plot to the right of the MORB field in an $\epsilon_{\mathrm{Nd}^{-}}$ $\epsilon_{\mathrm{Sr}}$ diagram, as do altered oceanic basalts. The data presented here suggest that this may be a characteristic of island arc rocks back to Cambrian times if they were derived by melting subducted oceanic slabs.

\section{Observed $\epsilon_{\mathrm{Nd}}-\epsilon_{\mathrm{Sr}}$ and Their Correlation}

We show a histogram of $\epsilon_{\mathrm{Nd}}$ for young oceanic and continental basalts and for the Bay of Islands Complex in Figure 6. The initial $\epsilon_{\mathrm{Nd}}$ values for the Bay of Islands samples are in the range from +6.5 to +8.1 , lie slightly lower than those for typical present-day midocean ridge tholeiites, and are thus clearly distinct from CFB. The Nd isotopic affinity with oceanic basalts can be easily seen. Richard et al. [1978] have reported $\epsilon_{\mathrm{Nd}}$ $(0)$ and $\epsilon_{\mathrm{Sr}}(0)$ values for some young ophiolitic gabbros that also indicate their oceanic nature.

We now examine how the Bay of Islands ophiolite data plot on the $\epsilon_{\mathrm{Nd}}-\epsilon_{\mathrm{Sr}}$ correlation diagram to determine whether the regularities observed for young oceanic samples also apply to old samples. Previous studies have shown that $\epsilon_{\mathrm{Nd}}$ and $\epsilon_{\mathrm{Sr}}$ correlate well, especially for ocean ridge and oceanic island basalts. This regularity does not appear to be valid for island arcs owing to $\mathrm{Sr}$ contamination by seawater [DePaolo and Wasserburg, 1976b, 1977; Hawkesworth et al., 1977]. Midocean ridge basalts have the highest $\epsilon_{\mathrm{Nd}}$ and lowest $\epsilon_{\mathrm{Sr}_{\mathrm{r}}}$ and a restricted range of values. Ocean islands have somewhat lower $\epsilon_{\mathrm{Nd}}$ and higher $\epsilon_{\mathrm{Sr}}$. The correlation is also valid for selected

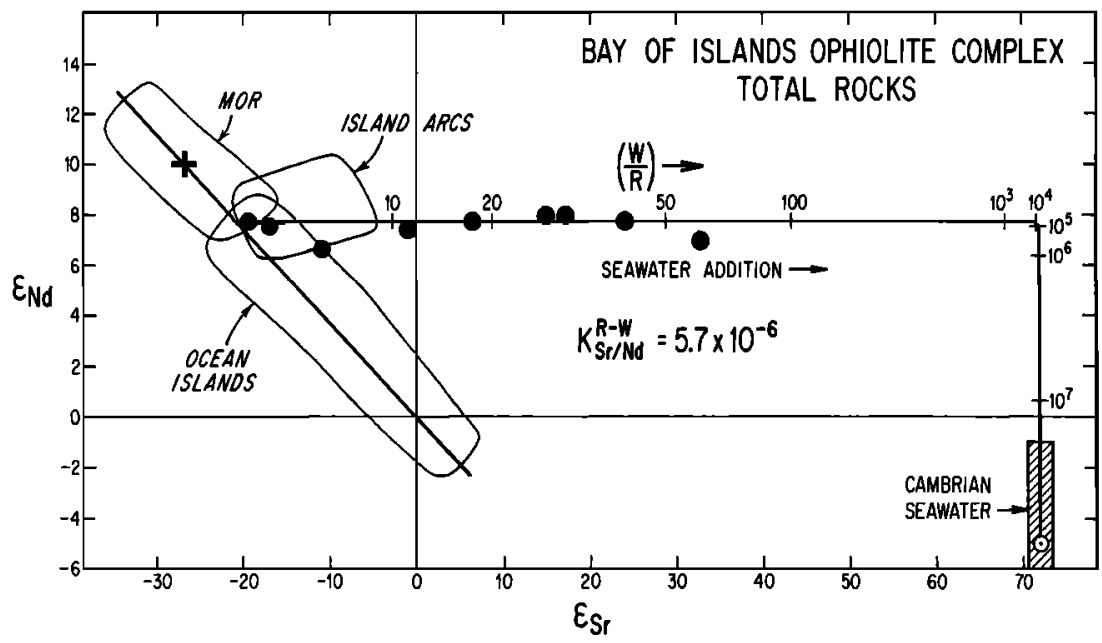

Fig. 7. An $\varepsilon_{\mathrm{Nd}}=\varepsilon_{\mathrm{Sr}}$ diagram showing the data for the Bay of Islands samples. The cross represents average modern MOR tholeiites. The line through this cross and $\varepsilon_{\mathrm{Nd}}=\varepsilon_{\mathrm{Sr}}=0$ represents the main correlation in young basaltic rocks ( $\varepsilon_{\mathrm{Nd}}$ $=-0.37 \varepsilon_{\mathrm{Sr}}$ ), which is called the Mantle Array. The fields of young MOR tholeiites, island are tholeiites, and ocean island basalts are shown. The $\varepsilon_{\mathrm{Nd}}$ and $\varepsilon_{\mathbf{S r}}$ values of the unaltered pyroxene gabbros plot on the Mantle Array and show that mantle sources of the early Paleozoic follow a pattern similar to that found in present-day mantle sources. The large dispersion in $\varepsilon_{\mathrm{Sr}}$ and an almost constant $\varepsilon_{\mathrm{Nd}}$ is due to interaction with Cambrian seawater. A mixing curve between seawater and the inferred composition of uncontaminated samples is given with the tick marks giving the volumetric water $(W / R)$ to rock ratio and show that $W / R>10^{5}$ before $\varepsilon_{\mathrm{Nd}}$ values are affected. 
continental basalts. The CFB have $\epsilon_{\mathrm{Nd}}$ in the neighborhood of zero but tend to spread out to very high $\epsilon_{\mathrm{Sr}_{\mathrm{r}}}$ values and negative $\epsilon_{\mathrm{Nd}}$ resulting from crustal contamination [DePaolo and Wasserburg, 1976b, 1979a]. Figure 7 shows the fields of various types of young basaltic rocks. The data for the pyroxene gabbros plot in the upper part of the oceanic island field and near the lower end of the MORB field. The field of island arc tholeiites also includes these data points. However, the structure and geochemistry of the Bay of Islands Complex strongly suggest that it formed at a chemically normal midocean ridge. Total rock samples of pillow basalts, dolerites, hornblende gabbros, and trondhjemites have high $\epsilon_{\mathrm{Sr}}$ values and plot to the right of the island arc field owing to submarine hydrothermal metamorphism. This behavior of Bay of Islands samples with shifts to the right is similar to that found for altered ocean floor basalts [O'Nions et al., 1977, 1978a]. We conclude from the data presented here that the primary magmatic $\epsilon_{\mathrm{Nd}}$ and $\epsilon_{\mathrm{Sr}}$ for the Bay of Islands Complex lie on the correlation line for young volcanic rocks and exhibit clear oceanic affinity. It follows that the mantle sources of early Paleozoic oceanic rocks follow a pattern similar to that found in young oceanic rocks. However, typical $\epsilon_{\mathrm{Nd}}$ and $\epsilon_{\mathrm{Sr}}$ values for young normal ridge segments are +10 and -27 , respectively (Figures 6 and 7). Therefore $\epsilon_{\mathrm{Nd}}$ values for the Bay of Islands Complex are displaced down along the correlation line by $\sim 2-3 \epsilon$ units from typical present-day MORB. We conclude from the data that the average initial $\mathrm{Nd}$ value for the Bay of Islands is $\epsilon_{\mathrm{Nd}}$ $=+7.6$, and for average initial $\mathrm{Sr}$ we assume that $\epsilon_{\mathrm{Sr}}=-19.3$ as for BMD-2A, since this value makes it plot on the correlation line. A shift toward lower $\epsilon_{\mathrm{Nd}}$ values and higher $\epsilon_{\mathbf{S r}}$ values is expected for old oceanic samples, since $f^{\mathrm{Sm} / \mathrm{Nd}}>0$ and $f^{\mathrm{Rb} / \mathrm{Sr}}$ $<0$ for the MORB source. However, in order to predict where the MORB field in Figure 7 should be for old samples, it is necessary to utilize specific models of mantle evolution.

This 0.5-aeon-old ophiolite has characteristic oceanic $\epsilon_{\mathrm{ND}}$ values which have been preserved both for altered and unaltered samples. This shows that the Nd isotopic signature may be used as a method to trace remnants of obducted oceanic crust in the Appalachian-Caledonian mountain chain in places where later tectonism and metamorphism have destroyed other geologic evidence.

\section{Comparison With Previous Age Data}

Late Precambrian flood basalt and associated feeder dikes that intrude Precambrian basement gneisses in northwest Newfoundland are overlain by arkosic sandstones and Lower Cambrian shales [Williams and Stevens, 1969]. They are believed to have formed during the initial continental rifting which produced the Proto-Atlantic (Iapetus) Ocean [Bird and Dewey, 1970]. Stukas and Reynolds [1974a] obtained a ${ }^{40} \mathrm{Ar} /$ ${ }^{39} \mathrm{Ar}$ age for these dikes of $615 \pm 10 \mathrm{~m}$.y., which they interpreted as the age of emplacement. All $\mathrm{K} / \mathrm{Ar}$ ages have been recalculated with the decay constants $\lambda_{\beta}=0.4962 \mathrm{aeon}^{-1}, \lambda_{\varepsilon}=$ 0.0581 aeon $^{-1}$, and ${ }^{40} \mathrm{~K}=0.01167$ atomic \%. The ophiolites in Newfoundland occur in allochthonous thrust slices, so a stratigraphic lower limit to their age is not well defined, but if the above arguments are correct, they should be younger than 615 m.y. Stratigraphic evidence further indicates that the main closure of Iapetus was completed by Middle Ordovician [Williams and Talkington, 1977]. Tremadocian sediments, associated with ophiolitic rocks of the Little Port Complex [Williams, 1973], indicate a minimum age of $\sim 490 \mathrm{~m} . \mathrm{y}$. The Little Port Complex is a polyphase deformed ophiolitic assemblage which lies to the west and is in steep structural and igneous contact with the Bay of Islands Complex [Karson and Dewey, 1978].

The Bay of Islands Complex was apparently emplaced on the continent while still at elevated temperatures, since a metamorphic aureole occurs along the surface of obduction. Amphiboles from the aureole give a ${ }^{40} \mathrm{Ar} /{ }^{39} \mathrm{Ar}$ age of $469 \pm 5$ m.y. [Dallmeyer and Williams, 1975] and a ${ }^{40} \mathrm{~K} /{ }^{40} \mathrm{Ar}$ age of 463 \pm 9 m.y. [Archibald and Farrar, 1976]. Amphiboles from sheeted dikes and gabbros give a ${ }^{40} \mathrm{~K}-{ }^{40} \mathrm{Ar}$ age of $461 \pm 12$ m.y. and an ${ }^{40} \mathrm{Ar} /{ }^{39} \mathrm{Ar}$ age of $467 \pm 7 \mathrm{~m}$.y. [Archibald and Farrar, 1976]. These ages ( $470 \mathrm{~m} . \mathrm{y}$.) were interpreted as the time of tectonic emplacement (obduction) of the ophiolite. Dated amphiboles within sheeted dikes and gabbros give argon ages indistinguishable from those of the metamorphic aureole. The time of final emplacement is bracketed by the middle Llanvirnian age of the youngest autochthonous rocks beneath the Humber Arm Allochthon and the late Llandeilian age of the oldest unit of the neoautochthonous Long Point Group which unconformably overlies the allochton [Bergström et al., 1974]. Using the revised Ordovician time scale of Churkin et al. [1977], this corresponds to $455-465 \mathrm{~m} . \mathrm{y}$. It appears that the Bay of Islands ophiolite was providing clastic detritus to greywackes of the Humber Arm Supergroup by the late Arenegian [Stevens, 1970], which indicates that the initial obduction of the ophiolite occurred at or before this stratigraphic time. The 470-m.y. age of the metamorphic aureole is currently used as an important reference point in the calibration of the absolute Ordovician time scale [Dallmeyer and Williams, 1975; Churkin et al., 1977].

$\mathrm{U}-\mathrm{Pb}$ data for zircons from a trondhjemite from within the Blow-Me-Down gabbro have been interpreted to give a time of crystallization of the complex of $504 \pm 10 \mathrm{~m}$.y., assuming that $\mathbf{4 6 0} \mathrm{m}$.y. represents a time of isotopic disturbance [ $\mathrm{Mat}$ tinson, 1976]. The three data points plot on a discordia line between these two times, but they are all within error of the concordia curve at significantly different times. This is because the concordia curve is nearly a straight line for this time inter$\mathrm{val}$, and it is thus difficult to interpret the U-Pb data. Mattinson [1975] reports U-Pb data on zircons from a trondhjemite of the adjacent Little Port Complex which give an age of 508 $\pm 5 \mathrm{~m}$.y. This was also interpreted as the time of crystallization of this complex. The data from this complex define a discordia between $T \sim 0$ and $T=510 \mathrm{~m}$.y., with all the data close to the upper intercept. There is no indication of a 470 m.y. event in the $\mathrm{U}-\mathrm{Pb}$ data, although amphiboles from this complex give $\mathrm{K}-\mathrm{Ar}$ ages of $\sim 470 \mathrm{~m}$.y. [Archibald and Farrar, 1976]. The U-Pb ages strictly provide only minimum age limits for these complexes. The Sm-Nd internal isochrons on gabbros BMD-2A and BMD-7 reported in this work give ages of $508 \pm 6 \mathrm{~m}$.y. and $501 \pm 13 \mathrm{~m}$.y. The similarity of the $\mathrm{Sm}-\mathrm{Nd}$ and $\mathrm{U}-\mathrm{Pb}$ ages gives further evidence for interpretation of this as the original time of crystallization of the oceanic crust now occurring in the Bay of Islands Complex.

Age data exist for two other ophiolites in Newfoundland. $\mathrm{U}-\mathrm{Pb}$ data on zircons from a trondhjemite dike cutting the Nippers Harbor (Betts Cove) ophiolite define a discordia between $T \sim 0$ and $T=463 \pm 6 \mathrm{~m}$.y., with all the data close to the upper intercept [Mattinson, 1975]. Mattinson interpreted this as the time of formation of the ophiolite. The Betts Cove ophiolite is overlain by Early Ordovician (Arenigian) sediments, so unless the Ordovician time scale is drastically revised, this suggests that the rock dated by Mattinson does not 
belong to the ophilite or that the U-Pb system in the zircons was reset during a later thermal event. $\mathrm{A}{ }^{40} \mathrm{Ar} /{ }^{39} \mathrm{Ar}$ age of 504 \pm 5 m.y. was determined by Stukas and Reynolds [1974b] on large crystals of primary hornblende from the Brighton gabbro, which intrudes the Lushs Bight sheeted dikes and pillow lavas in central Newfoundland. The age was interpreted with some caution as the time of primary crystallization.

The precise times of formation of these ophiolites and their time of emplacement are important in plate tectonic models for the Appalachian-Caledonian mountain chain and for establishing the absolute time scale of the lower Paleozoic. From the data outlined above, the times of formation of the Bay of Islands Complex, both as a segment of oceanic crust at $505 \mathrm{~m}$.y. and of obduction at $\mathbf{4 7 0}$ m.y., seem now to be well established.

\section{MODELS FOR THE EVOLUTION OF THE SOURCE of Midocean Ridge Basalts}

From the $\epsilon_{\mathrm{Nd}}$ and $\epsilon_{\mathrm{Sr}}$ values of midocean ridge basalts it is clear that the MORB have been derived from a mantle reservoir that has suffered depletion of LIL elements and this reservoir must have existed for long times. The only plausible long-lived LIL element enriched reservoir that could be the complement to the MORB source is the continental crust. The MORB source is thus likely to have formed as a residue after previous partial melting events in the mantle that formed part or all of the continental crust.

\section{Discrete Differentiation Event}

For simplicity, let us first consider a model in which a LILdepleted and a LIL-enriched reservoir is formed by partial melting from an undifferentiated reservoir (CHUR, UR) in a single differentiation event at time $T_{D}$. Then as shown by $D e-$ Paolo and Wasserburg [1976a], at a time $T$ subsequent to the time of differentiation $T_{D}$ we have to a good approximation

$$
\begin{gathered}
\epsilon_{\mathrm{Nd}}(T)=Q_{\mathrm{Nd}} f^{\mathrm{Sm} / \mathrm{Nd}}\left(T_{D}-T\right) \\
\epsilon_{\mathrm{Sr}}(T)=Q_{\mathrm{Sr}} f^{\mathrm{Rb} / \mathrm{Sr}}\left(T_{D}-T\right)
\end{gathered}
$$

where

$$
\begin{aligned}
Q_{\mathrm{Nd}} & \equiv \frac{\lambda_{\mathrm{Sm}}\left({ }^{147} \mathrm{Sm} /{ }^{144} \mathrm{Nd}\right)_{\mathrm{CHUR}}{ }^{0} \cdot 10^{4}}{I_{\mathrm{CHUR}}{ }^{\mathrm{Nd}}(0)}=24.74 \mathrm{aeon}^{-1} \\
Q_{\mathrm{Sr}} & \equiv \frac{\left.\lambda_{\mathrm{Rb}}{ }^{87} \mathrm{Rb} /{ }^{86} \mathrm{Sr}\right)_{\mathrm{UR}}{ }^{0} \cdot 10^{4}}{I_{\mathrm{UR}}{ }^{\mathrm{Sr}}(0)}=16.70 \mathrm{aeon}^{-1}
\end{aligned}
$$

and $f$ is the enrichment factor for either the LIL-depleted residue after melting $\left(f_{s}\right)$ or the LIL-enriched partial melt $\left(f_{m}\right)$. Using $f_{m}$ as measured for the sample, the time $T_{D}$ calculated for $\epsilon_{\mathrm{Nd}}(0)$ and $\epsilon_{\mathrm{Sr}}(0)$ (at $T=0$ ) corresponds to $T_{\mathrm{CHUR}}{ }^{\mathrm{Nd}}$ and $T_{\mathrm{UR}}{ }^{\mathrm{Sr}}$ for $\mathrm{Sm} / \mathrm{Nd}$ and $\mathrm{Rb} / \mathrm{Sr}$, respectively, as defined by McCulloch and Wasserburg [1978]. The $f$ values for the parent reservoirs are not measured directly; in particular, for the depleted residue it is necessary to make some estimates of the $f_{s}$ values to find $T_{D}$ for the MORB source from (5). In the section on the LIL element patterns we estimated $f_{s}{ }^{\mathrm{Rb} / \mathrm{Sr}}=-0.9$ and $f_{s} \mathrm{Sm} / \mathrm{Nd}=+0.22$. For a simple model with a single differentiation event these $f_{s}$ values should be the same for all time in the LIL-depleted residue. Normal modern MORB have average $\epsilon_{\mathrm{Sr}}=-27$ and $\epsilon_{\mathrm{Nd}}=+10$, so by using the above $f_{s}$ values and (5) we get $T_{D}$ of 1.8 aeons for both $\mathrm{Sm} / \mathrm{Nd}$ and $\mathrm{Rb} / \mathrm{Sr}$. As $f_{s}^{\mathrm{Rb} / \mathbf{S}_{\mathbf{r}}}$ is close to its limit of -1 , it is therefore not subject to substantial error. Since $f_{s}^{\mathrm{Rb} / \mathrm{Sr}}>-1$, it also follows that $\mathbf{T}_{\mathrm{D}}>$
1.6 aeons. Note that we use average values estimated for the MORB source reservoir for these calculations.Carlson et al. [1978] used $f^{\mathrm{sm}^{\mathrm{si} d}}$ and $\epsilon_{\mathrm{Nd}}$ values for individual MORB samples and obtained a diversity of $T_{\mathrm{CHUR}}{ }^{\mathrm{Nd}}$ model ages (1.0-1.3 aeons). Whether this dispersion reflects real variation in source ages or changes in $f^{\mathrm{Sm} / \mathrm{Nd}}$ during magmatic differentiation is not yet understood. Typical values for the Bay of Islands source from the data in this paper were inferred to be $\epsilon_{N d}=$ +7.6 and $\epsilon_{S r}=-19.3$. Using these values, the age of 0.5 aeon and the above $f_{s}$ values give $T_{D}$ of 1.9 and 1.8 aeon for $\mathrm{Sm} / \mathrm{Nd}$ and $\mathrm{Rb} / \mathrm{Sr}$, respectively. The fact that we get nearly the same value for $T_{D}$ for two different points in time could be taken as evidence that this time represents a unique differentiation event. Note, however, that the depleted mantle could also be produced over a time of the order of 3.6 aeons and have a mean age of 1.8 aeons, and the value of $T_{D}$ calculated does thus not necessarily define a single event. In discussing whether the MORB source was in fact produced in a single event, it is necessary to address the problem of whether a single-event model can explain the dispersion in the data for young MORB samples and also the mantle array (Figure 9). We will therefore discuss how $\epsilon_{\mathrm{Nd}}$ and $\epsilon_{\mathrm{Sr}}$ depend on the times of differentiation and $\mathrm{Rb} / \mathrm{Sr}$ and $\mathrm{Sm} / \mathrm{Nd}$ fractionations in the mantle by assuming equilibrium melting.

\section{Modeling of Fractionation Patterns in the MORB Source and the Timing of Fractionation Events}

It has been shown previously that modeling the relationship between $f^{\mathrm{Rb} / \mathrm{Sr}}$ and $f^{\mathrm{Sm} / \mathrm{Nd}}$ for melts and residual solid can aid in the interpretation of $\mathrm{Sm}-\mathrm{Nd}$ and $\mathrm{Rb}-\mathrm{Sr}$ isotopic data [O'Nions et al., 1977; Carter et al., 1978; O'Nions et al., 1978b; Hawkesworth et al., 1978; DePaolo, 1979].

In the following we discuss the systematics of $\epsilon_{\mathrm{Nd}}$ and $\epsilon_{\mathrm{S}}$ values and the $f^{\mathrm{Rb} / \mathrm{Sr}}$ and $f^{\mathrm{Sm} / \mathrm{Nd}}$ in the residual solid which is the parent reservoir of the basalts. The residual solid is assumed to be produced after partial melting of an undepleted mantle reservoir. We assume equilibrium partial melting. The relationship between $\epsilon_{\mathrm{Nd}}$ and $\epsilon_{\mathrm{Sr}}$ in the depleted reservoir depends on the function $G$ :

From (5) and (6) we get

$$
f_{s}^{\mathrm{Sm} / \mathrm{Nd}}=\boldsymbol{G}\left(f_{s}^{\mathbf{R b} / \mathbf{S r}}\right)
$$

$$
\epsilon_{\mathrm{Nd}}(T)=Q_{\mathrm{Nd}}\left(T_{D}-T\right) G\left(\frac{\epsilon_{\mathrm{Sr}}(T)}{Q_{\mathrm{Sr}}\left(T_{D}-T\right)}\right)
$$

For melting where complete chemical equilibrium is maintained between bulk liquid and all phases present in the solid, the previous melting history is not relevant if the system remains closed. The bulk distribution coefficient is defined by

$$
D=\frac{C_{s}}{C_{m}}=\sum_{i} X_{i} K_{r}
$$

where $C_{s}$ is the concentration in the solid, $C_{m}$ the concentration in the liquid, $X_{i}$ the mass fraction of mineral $i$ in residual solid, and $K_{i}$ the mineral/melt partition coefficient for mineral $i$. The concentration in the melt relative to that in the initial total system $C_{0}$ is given by

$$
\frac{C_{m}}{C_{0}}=\frac{1}{F+D(1-F)}
$$

where $F$ is the mass fraction of the system that is present as 


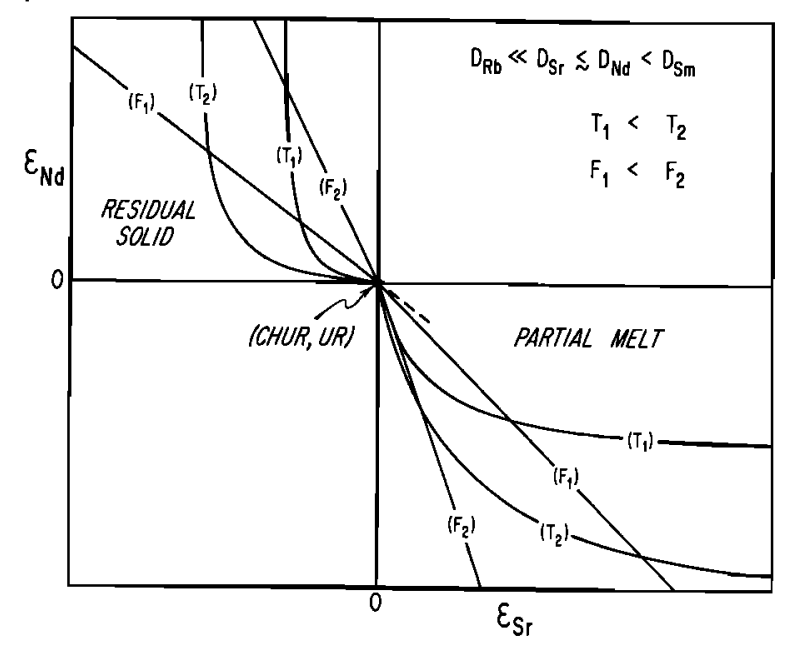

Fig. 8. Cartoon showing the expected relationships between residual solid and partial melts in an $\epsilon_{\mathrm{Nd}}=\epsilon_{\mathrm{Sr}}$ diagram at $T_{1}$ and $T_{2}$ years subsequent to the melting event and for various degrees of melting $F$. The line segments of constant $F$ cover a range of times. The intersection of a constant $T$ curve with a constant $F$ curve determines the values of $F$ and $T$ at that point.

melt [Shaw, 1970; Consolmango and Drake, 1976]. The concentration in the residual solid is given by

$$
\frac{C_{s}}{C_{0}}=\frac{D}{F+D(1-F)}
$$

where $D$ is a function of the degree of melting. Assuming that the phases always melt in constant proportions, then $D$ is related to the initial bulk distribution coefficient $D_{0}=\sum_{d} X_{1}^{0} K_{r}$, where $X_{i}^{0}$ is the mass fraction of mineral $i$ in the original solid. Let $p_{i}$ be the mass fraction of mineral $i$ in the melt and $P=$ $\sum_{i} p_{i} K_{i}$. Then

$$
\begin{gathered}
D=\sum_{i} \frac{X_{1}^{0}-F p_{i}}{1-F} K_{i}=\frac{D_{0}-F P}{1-F} \\
\frac{C_{m}}{C_{0}}=\frac{1}{D_{0}+F(1-P)}
\end{gathered}
$$

which are equations (12) and (15) of Shaw [1970]. For the residual solid, (8) and (11) give

$$
\frac{C_{s}}{C_{0}}=\frac{D_{0}-P F}{1-F}\left(\frac{C_{m}}{C_{0}}\right)=\frac{D_{0}-P F}{(1-F)\left[D_{0}-F(1-P)\right]}
$$

Enrichment factors for liquid and residual solid as a function of $F$ are then given by

$$
\begin{gathered}
\int_{m}^{\mathrm{sm} / \mathrm{Nd}}=\frac{D_{0, \mathrm{Nd}}+F\left(1-P_{\mathrm{Nd}}\right)}{D_{0, \mathrm{Sm}}+F\left(1-P_{\mathrm{Sm}}\right)}-1 \\
f_{s}^{\mathrm{sm} / \mathrm{Nd}}=\frac{\left(D_{0, \mathrm{Sm}}-P_{\mathrm{Sm}} F\right)\left[D_{0, \mathrm{Nd}}+F\left(1-P_{\mathrm{Nd}}\right)\right]}{\left(D_{0, \mathrm{Nd}}-P_{\mathrm{Nd}} F\right)\left[D_{0, \mathrm{Sm}}+F\left(1-P_{\mathrm{Sm}}\right)\right]}-1
\end{gathered}
$$

Equivalent formulas hold for $f_{m}{ }^{\mathrm{Rb} / \mathrm{sr}}$ and $f_{s}{ }^{\mathrm{Rb} / \mathrm{sr}}$. The function $G$ is thus determined by formulas for $f_{s}{ }^{R b / S r}$ and $f_{s} S_{m} / \mathrm{Na}$ through the fraction of melt $F$. Equations analogous to (14) have been given by DePaolo [1979] for equilibrium melting and fractional melting in the special case when $D_{0}=P$.

The limiting slope for the residual solid as $F \rightarrow 0$ is

$$
\lim _{F \rightarrow 0}\left(\frac{d f_{s}^{\mathrm{Sm} / \mathrm{Nd}}}{d f_{s}^{\mathrm{Rb} / \mathrm{Sr}}}\right)=\frac{D_{0, \mathrm{Sm}^{-1}}-D_{0, \mathrm{Nd}}{ }^{-1}}{D_{0, \mathbf{R b}}{ }^{-1}-D_{0, \mathrm{Sr}}^{-1}}=\left(\frac{f_{s}^{\mathrm{Sm} / \mathrm{Nd}}}{f_{s}^{\mathrm{Rb} / \mathrm{Sr}}}\right)_{F=0}
$$

DePaolo [1979] has shown that (15) also holds for modal equilibrium melting and modal fractional melting. It can in fact be shown from (10) that (15) holds for any kind of equilibrium melting.

The relationships between $\epsilon_{\mathrm{Nd}}$ and $\epsilon_{\mathrm{Sr}}$ in the residual solid subsequent to a partial melting event at time $T_{D}$ may be calculated from (5) and (14). Basalts generated by subsequent melting of the residue will have $\epsilon_{\mathrm{Nd}}$ and $\epsilon_{\mathrm{S}_{\mathrm{T}}}$ values of the residue at the time of later melting as given by (5) for $\int_{s}{ }^{\mathrm{Rb} / \mathrm{Sr}_{\mathrm{r}}}$ and $f_{s}^{\mathrm{Sm} / \mathrm{Nd}}$ calculated from (14). A cartoon illustrating various constant $\left(T_{D}-T\right)$ curves and constant $F$ curves is shown in Figure 8 for the case where $D_{\mathrm{Rb}} \ll D_{\mathrm{Sr}} \leqslant D_{\mathrm{Nd}}<D_{\mathrm{Sm}}$. For a constant gree of melting or for asymptotically small amounts of melting, $f_{s}^{\mathrm{S} m / \mathrm{Nd}}=\alpha f_{s}^{\mathrm{Rb} / \mathrm{S}_{\mathrm{r}}}$, where $\alpha$ is a constant which may be calculated from (14). It follows that

$$
\epsilon_{\mathrm{Nd}}(T)=\frac{\alpha Q_{\mathrm{Nd}}}{Q_{\mathrm{Sr}}} \epsilon_{\mathrm{Sr}}(T)
$$

All reservoirs with the same degree of melting will thus lie on a line for all times. The position of the melt on the line will depend on $\left(T_{D}-T\right)$ as given by (5). The area in Figure 8 labeled partial melt corresponds to the evolution in time of the melt removed from the residual solid at $T_{D}$. This complementary material presumably represents crustal material formed at that time. For a constant degree of melting the relationship between the slopes for residual solid and partial melt is given by

$$
\frac{\left(d \epsilon_{\mathrm{Nd}} / d \epsilon_{\mathrm{Sr}}\right)_{m}}{\left(d \epsilon_{\mathrm{Nd}} / d \epsilon_{\mathrm{Sr}}\right)_{s}}=\frac{D_{\mathrm{Nd}}}{D_{\mathrm{Sr}}}=\frac{(\mathrm{Sr} / \mathrm{Nd})_{m}}{(\mathrm{Sr} / \mathrm{Nd})_{s}}
$$

The break in slope at the origin for constant $F$ curves may be calculated from (17). For various degrees of melting, all reservoirs with the same value of $\left(T_{D}-T\right)$ will lie on a curve whose shape depends on the function $G$ in (6). Figure 8 shows schematically the relationship between lines and curves expected for different values of $F$ and $\left(T_{D}-T\right)$. If we derive magmas today from residual mantle reservoirs formed in a partial melting event $T_{1}$ years ago with a range in degree of melting between $F_{1}$ and $F_{2}$, then they should have initial $\epsilon_{\mathrm{Nd}}$ and $\epsilon_{\mathrm{Sr}}$ which plot on the curve for $\left(T_{D}-T\right)=T_{1}$ and be bounded by the intersections with the lines labeled $F_{1}$ and $F_{2}$. We note that since depleted mantle reservoirs have $\mathrm{Sr} / \mathrm{Nd}$ ratios close to chondritic, mixing curves between depleted and undepleted reservoirs would be essentially straight lines between the end-members. If mixing occurred between these reservoirs and an undepleted mantle reservoir at the origin, then magmas derived today may have values anywhere in the field bounded by the curve $T_{1}$ and the lines $F_{1}$ and $F_{2}$.

We will now apply the above relations to a specific example. For the original unfractionated reference reservoir we assume a fertile garnet peridotite mineralogy with the initial mass fractions of the various phases: olivine $=0.55$, orthopyroxene $=0.15$, clinopyroxene $=0.15$, and garnet $=0.15$. Various mineralogies have been suggested on the basis of modeling of geophysical data [Ahrens, 1973], the modal abundances in mantle xenoliths [Harris et al., 1967; Jackson and Wright, 1970; Carter, 1970; Maalde and Aoki, 1977], and geochemical models [Ringwood, 1975]. Our choice is fairly similar to the pyrolite model of Ringwood [1975]. The melting proportions of the above phases are assumed to be $0.03,0.07,0.45$, and 0.45 , respectively, and will leave a residue of harzburgite after 33\% melting. The LIL element distribution are not sen- 


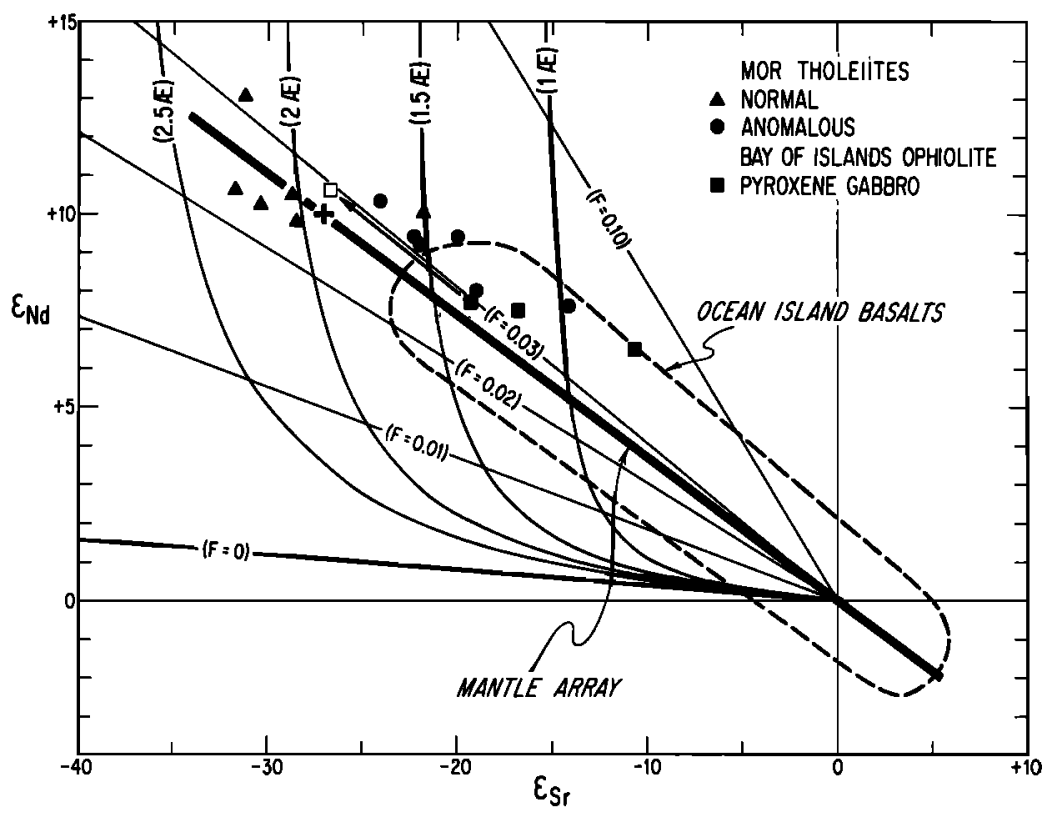

Fig. 9. An $\epsilon_{\mathrm{Nd}}=\epsilon_{\mathrm{Sr}}$ diagram showing data for young MOR tholeiites and the 505-m.y.-old Bay of Islands pyroxene gabbros. Constant $T_{D}$ curves are shown for a range of ages from 1 to 2.5 aeons (AE) and were calculated using the partial melting model discussed in the text. Constant degree of melting curves are also shown. Typical values for the Bay of Islands source are inferred to be $\epsilon_{\mathrm{Nd}}=+7.6$ and $\epsilon_{\mathrm{Sr}}=-19.3$, identical to the values for one of the pyroxene gabbros (BMD-2A). This corresponds to $F=0.03$ and a time $\left(T_{D}-T\right)$ of 1.35 aeons, which corresponds to an isolation of the source 1.85 aeons ago. The expected value for the Bay of Islands source, if sampled today, is shown by the open square and is close to the average value for modern MOR tholeiites (cross).

sitive to the choice of eutectic proportions. The distributions coefficients used (Table 5) were selected, if possible, for basaltic systems at temperatures of $1200^{\circ}-1300^{\circ} \mathrm{C}$. The mineralogy used in the present model gives the following bulk distribution coefficients: $D_{0, \mathrm{Rb}}=0.0025, D_{0, \mathrm{Sr}}=0.033, D_{0, \mathrm{Nd}}=0.044$, and $D_{0, \mathrm{Sm}}=0.080$. The melting proportions used give $P_{\mathrm{Rb}}=0.006$, $P_{\mathrm{Sr}}=0.091, P_{\mathrm{Nd}}=0.12$, and $P_{\mathrm{Sm}}=0.21$.

The resulting constant $F$ and constant $\left(T_{D}-T\right)$ curves are shown in an $\epsilon_{\mathrm{Nd}^{-}}-\epsilon_{\mathrm{Sr}}$ diagram together with the data for MOR tholeiites and the Bay of Islands ophiolite (Figure 9). The calculated constant $\left(T_{D}-T\right)$ curves all have an initital slope given by the line labeled $F=0$. This initial slope is much less than that of the Mantle Array, so it cannot be explained by asymptotic behavior of the constant $\left(T_{D}-T\right)$ curves. With increasing degree of melting the constant $\left(T_{D}-T\right)$ curves get steeper and intersect the Mantle Array. The shape of these curves is a result of the fact that the bulk distribution coefficients $D_{\mathrm{Rb}} \ll D_{\mathrm{Sr}} \leqslant D_{\mathrm{Nd}}<D_{\mathrm{Sm}}$ for our choice of source mineralogy. From the distribution coefficients given in Table 5, it seems likely that the constant $\left(T_{D}-T\right)$ curves would have this shape for the most reasonable choices of source mineralogy if the major phases are controlling the LIL element fractionation during partial melting. If minor phases like amphibole, phlogopite, or apatite are important residual phases, then this is not necessarily true (Table 5), and the Mantle Array could possibly be due to asymptotic behavior of the constant $\left(T_{D}-T\right)$ curves. However, then this would require that the initial mineralogy melted always should have constant proportions of these minor phases to satisfy (15). We feel that at present there is insufficient evidence for this and conclude that the shape of the constant $\left(T_{D}-T\right)$ curves in Figure 9 is correct. We also note that the degree of melting assigned to each point on a constant $\left(T_{D}-T\right)$ curve will be much more model dependent than the shape of the curve, since the steep part is due to the fact that as $f^{\mathbf{R b} / \mathbf{s} r}$ approaches its lower limit of -1 , the position of the curve is not model dependent.

The data points for pyroxene gabbros from the Bay of Islands Complex are shown in Figure 9. As discussed previously, the gabbro with the lowest $\epsilon_{\mathbf{S}}$ value is thought to have the typical value of $\epsilon_{\mathrm{Nd}}$ and $\epsilon_{\mathrm{S}}$ for the Bay of Islands source. Using the time grid on Figure 9, this corresponds to an intersection of a curve with $\left(T_{D}-T\right)=1.35$ aeons and a line with $\boldsymbol{F}=\mathbf{0 . 0 3}$. The source may thus have been derived from a layer segregated 1.35 aeons prior to the formation of the 0.5 -aeonold Bay of Islands Complex, which corresponds to an isolation of the source 1.85 aeons ago. This is again consistent with the $T_{D}$ value obtained previously for young MORB. This single-stage model allows us to evaluate the position of the Bay of Islands source if it had evolved up to the present instead of being partially melted $\sim 500 \mathrm{~m} . y$. ago. This displacement is shown by the arrow in Figure 9 and indicates that the Bay of Islands source would have had $\epsilon_{\mathrm{Nd}} \sim 10.5$ and $\epsilon_{\mathrm{Sr}} \sim-27$ if it had evolved up to today in this single-stage model.

TABLE 5. Mineral/Melt Partition Coefficients

\begin{tabular}{lllll}
\hline & Rb & \multicolumn{1}{c}{ Sr } & Nd & Sm \\
\hline Clinopyroxene & 0.003 & 0.12 & 0.17 & 0.26 \\
Garnet & 0.01 & 0.08 & 0.087 & 0.217 \\
Orthopyroxene & 0.003 & 0.02 & 0.013 & 0.022 \\
Olivine & 0.0002 & 0.0002 & 0.007 & 0.010 \\
Amphibole & 0.045 & 0.188 & 0.19 & 0.34 \\
Phlogopite & 3.0 & 0.081 & 0.03 & 0.03 \\
Apatite & $\cdots$ & $\cdots$ & 26 & 20
\end{tabular}

Sources are Griffin and Murthy [1969], Philpotts and Schnetzler [1970], Schnetzler and Philpotts [1970], Hart and Brooks [1974], Shimizu [1974], Grutzeck et al. [1975], Shimizu and Kushiro [1975], Weill and McKay [1975], McKay and Weill [1976], and Beswick and Carmichael [1978]. 
It is of special interest here to look in detail at the data base for present day MORB. Figure 9 shows existing data for normal and chemically anomalous MOR tholeittes. The data for anomalous MORB [O'Nions et al., 1977; Richard et al., 1976] are mainly from the geochemical transition zone south of the Azores and have trace element and isotopic characteristics intermediate between the Azores platform and normal ridge tholeiites [White and Schilling, 1978]. One sample [O'Nions et $a l ., 1977]$ is from the geochemical gradient observed along the Reykjanes Ridge south of Iceland [Schilling, 1973; Sun et al., 1975]. The data for normal MORB spread out along the Mantle Array as shown in Figure 9, and the data cannot be explained as samples of different reservoirs with different $f_{s}$ values formed at one time, since they do not follow the steep part of any constant $\left(T_{D}-T\right)$ curve. The diagram rather indicates that the source of the normal MORB formed as residue after melting over a time interval from $\sim 2.3$ to 1.5 aeons ago with a relatively constant degree of melting of $F=0.025-$ 0.40 to form the continents. The MORB may, of course, represent an arbitrary degree of melting which is not directly related to the values of $F$ given here. The average MORB represented by the cross in Figure 9, indicates that the mean value of $T_{D}$ is 1.9 aeons for the MORB source today. The anomalous MORB are displaced toward somewhat lower $\epsilon$ values along the Mantle Array. Younger differentiation ages are thus indicated for the source of anomalous MORB in the range from 1.7 to 1.0 aeons ago. The oceanic island magmas mainly cluster around $\epsilon_{\mathrm{Nd}}=+6$ but spread out along the correlation line to $\epsilon_{\mathrm{Nd}} \sim 0$, and this may indicate even younger differentiation ages for their sources. We conclude that while it is possible to explain the MORB data alone by partial melting of a reservoir formed in a unique event, it is not possible to explain the anomalous MORB or the Mantle Array by such a one-stage model. It is possible that one may have a variety of depleted mantle reservoirs formed at different times owing to partial melting events with relatively constant degree of melting. The set of all such reservoirs would, if sampled today, plot on a line. One may thus get the Mantle Array by having layers of different $T_{D}$ and with $F$ in the range from $\sim 0.02$ to 0.04 as indicated in Figure 9. Today this would give the isotopic characteristics of basalts which lie on the correlation line. Mixtures of such reservoirs formed at different times would then also always lie on the correlation line. The simplest choice is to have only two reservoirs, the samples with isotopic characteristics intermediate between these two reservoirs being blends of these two sources. The simplest choice of end-members is the endpoints of the Mantle Array. We thus choose the source of normal MORB for the LIL-depleted end-member and the origin (CHUR, UR) as the undepleted end-member. This model must still explain the scatter around the Mantle Array which is not addressed here. The age of the undepleted reservoir is 4.55 aeons, while the age of the depleted reservoir is probably of the order of 3.6 aeons, as discussed previously, and its mean age is $\sim 1.8$ aeons. Interpretation of the Mantle Array as a mixing line is basically in agreement with the interpretations by Schilling [1973], Sun et al. [1975], and White and Schilling [1978] that anomalous MORB magmas are derived by mantle plume mixing with a LIL-depleted asthenosphere. We conclude that the Mantle Array may be most simply explained as a result of mixing of the MORB source and an undifferentiated mantle source [DePaolo and Wasserburg, 1976b; Hawkesworth et al., 1978; DePaolo and Wasserburg, 1979a; DePaolo, 1979].

\section{Significance of Differentiation Ages} for the MORB Source

Single-stage $\mathrm{Rb}-\mathrm{Sr}$ and $\mathrm{Sm}-\mathrm{Nd}$ differentiation ages for the MORB source give $\sim 1.8$ aeons. This is similar to differentiation ages derived from mantle isochrons [Sun and Hanson, 1975; Sun and Jahn, 1975; Brooks et al., 1976a, b; Church and Tatsumoto, 1975; Tatsumoto, 1978] for both MORB and ocean island basalts. This would suggest that the widespread formation of continental crust $\sim 1.8$ aeons ago is coincident with the formation of the MORB source reservoir. We believe that a single differentiation event cannot explain the $\epsilon_{\mathrm{Nd}}$ and $\epsilon_{\mathrm{Sr}}$ data for MORB and the Mantle Array and that the range in observed values is most likely due to mixing of depleted mantle with undepleted mantle. The continental crust is also known to have formed in many events, with the most important occurring at $\sim 0,0.5,1.0,1.8,2.6$, and 3.6 aeons ago. Each crustforming event must also have produced a complementary depleted mantle reservoir. The average $f_{s}^{\mathrm{Sm} / \mathrm{Nd}}$ value for the depleted mantle is +0.22 , so we should see a range of $\epsilon_{\mathrm{Nd}}$ values from 0 to +20 for depleted mantle formed over a time span of 3.6 aeons if no mixing occurred in the depleted mantle. Instead, the normal oceanic mantle shows a rather limited range from +8 to +12 , implying relatively rapid mixing in the depleted mantle. The average $f^{\mathrm{Sm} / \mathrm{Nd}}$ is +0.12 for the upper oceanic crust and is +0.42 for the lower oceanic crust. If large blocks of the oceanic crust made up of these different materials were preserved, then heterogeneities of $\sim 4 \epsilon_{\mathrm{Nd}}$ units should develop on a time scale of 0.5 aeon unless these units get well mixed after being subducted back to the oceanic mantle. As the total range in $\epsilon_{\mathrm{Nd}}$ today is $\sim 4 \epsilon$ units and the Bay of Islands Complex gives an $\epsilon_{\mathrm{Nd}}$ value consistent with the mean $\int_{s}^{\mathrm{Sm} / \mathrm{Nd}}$ value for the MORB source, we therefore infer that rapid mixing must have occurred in the oceanic mantle for at least the last 1.0 aeon. The reason that we get consistent differentiation ages for the MORB source from two decay systems using its average $\epsilon$ and $f$ values is thus likely to be due to the oceanic mantle having been relatively well mixed through time rather than having it formed in a discrete event. The mantle isochrons referred to above are thus interpreted as mixing lines between undepleted mantle and depleted mantle of mean age $\sim 1.8$ aeons. This times does not refer to any differentiation event, and the time scale of formation of this reservoir must be of the order of 3.6 aeons, which is compatible with the evidence from ages of continental crustal rocks. In a companion paper on mean ages of mantle and crustal reservoirs [Jacobsen and Wasserburg, 1979] we will discuss models where the continental crust and a complementary depleted mantle reservoir are built gradually throughout the history of the earth.

\section{CONCLUSIONS}

The time of crystallization of the Bay of Islands Complex has been determined as $508 \pm 6 \mathrm{~m} . \mathrm{y}$. and $501 \pm 13 \mathrm{~m} . \mathrm{y}$. by two $\mathrm{Sm}$-Nd mineral isochrons on the pyroxene gabbros from the Blow-Me-Down massif. This time refers to the time of crystallization as a part of the Iapetus oceanic crust. This age agrees with a previously determined age by $\mathrm{U}-\mathrm{Pb}$ on zircons from a trondhjemite and demonstrates the usefulness of the $\mathrm{Sm} / \mathrm{Nd}$ technique for dating gabbroic rocks in ophiolites. The time of obduction of the Bay of Islands Complex is determined by previously published $\mathrm{K}-\mathrm{Ar}$ ages as $470 \mathrm{~m} . \mathrm{y}$.

The oceanic nature of the complex was previously demonstrated by its structure and petrology. The LIL element pat- 
terns and isotopic data presented here are clearly in agreement with this interpretation. The origin of many early Paleozoic greenstone sequences, gabbros, and ultramafics is uncertain owing to the fact that later metamorphism and tectonism have obliterated evidence for their oceanic or continental nature. It appears that the distinctive $\epsilon_{\mathrm{Nd}}$ values of oceanic crust may now be used to identify ancient obducted oceanic lithosphere.

A small range of initial $\mathrm{Nd}$ of $\epsilon_{\mathrm{Nd}}=+6.5$ to +8.1 is observed for different rocks within the complex including an orthopyroxenite layer from the harzburgite, whereas the initial Sr on the same samples show a large range of $\epsilon_{\mathrm{s} r}$ from -19 to +33 . The observed change in $\epsilon_{\mathrm{Nd}}$ from +7.6 to +10 for the oceanic mantle over the last 0.5 aeon is quantitatively expectable for a simple single-stage model of mantle evolution. The large range observed in $\epsilon_{\mathrm{S}_{\mathrm{r}}}$ values cannot be explained by mantle evolution. The wide range in $\epsilon_{\mathrm{S} r}$ with an almost constant $\epsilon_{\mathrm{Nd}}$ is due to major interaction with seawater and thus show that the early Paleozoic ocean floors were also important sinks for radiogenic crustal $\mathrm{Sr}$.

Modeling of the Rb-Sr and Sm-Nd fractionation patterns in the source of MORB strongly suggests that the data array cannot be explained by a single differentiation event to form the depleted mantle but instead most likely requires mixing of depleted and undepleted mantle sources. Single-stage differentiation ages for the source of MORB are identical for modern MORB and the Bay of Islands Complex and give $\sim 1.8$ aeons. This is similar to previously proposed differentiation ages derived from mantle isochrons. This age is, however, interpreted as the mean age of the MORB source and does not refer to a unique event. The total time for producing this source by a uniform process would be of the order of 3.6 aeons.

Normal MORB today show a limited range of $\epsilon_{\mathrm{Nd}}$ from +8 to +12 . This limited range and the consistent results for the 0.5-aeon-old Bay of Islands Complex must imply relatively rapid mixing in the source of the MORB for at least the last 1 aeon.

Acknowledgments. We wish to thank N. Christensen and H. Williams for their advice during the planning of the field work in Newfoundland and $\mathrm{H}$. Williams for his hospitality. We particularly appreciate $\mathbf{H}$. Williams's cleansing of the ophiolite samples from possible tuber malignancies and his help with importing the specimens. $\mathbf{N}$. Christensen also provided one of the samples so that some data could be gathered prior to the field work during the summer of 1978. D Papanastassiou, M. McCulloch, and the reviewers $H$. Williams and W. M. White provided numerous helpful comments and suggestions on the manuscript. We also want to thank A. M. Ziegler for stimulating discussions of the ophiolite problem. This work has been supported by NSF grant EAR 76-22494. Division of Geological and Planetary Sciences contribution 3210 (291).

\section{REFERENCES}

Ahrens, T. J., Petrologic properties of the upper $670 \mathrm{~km}$ of the earth's mantle: Geophysical implications, Phys. Earth Planet. Interiors, 7, 167-186, 1973.

Allègre, C. J., R. Montigny, and Y. Bottinga, Cortège ophiolitique et cortège oceanique, géochimie comparée et mode de genèse, Bull. Soc. Geol. Fr., 15, 461-477, 1973.

Archibald, D. A., and E. Farrar, K-Ar ages of amphiboles from the Bay of Islands ophiolite and the Little Port Complex, Western Newfoundland, and their geological implications, Can. J. Earth Sci., 13, 520-529, 1976.

Bergström, S., J. Riva, and M. Kay, Significance of conodonts, graptolites and shelly faunas from the Ordovician of western and northcentral Newfoundland, Can. J. Earth Sci., 11, 1025-1160, 1974.

Beswick, A. E., and I. S. E. Carmichael, Constraints on mantle source compositions imposed by phosphorus and rare-earth elements, Contrib. Mineral. Petrol., 67, 317-330, 1978.
Bird, J. M., and J. F. Dewey, Lithosphere plate-continental margin tectonics and the evolution of the Appalachian orogen, Geol. Soc. Amer. Bull., 8I, 1031-1060, 1970.

Brooks, C., S. R. Hart, A. Hoffman, and D. E. James, Rb-Sr mantle isochrons from oceanic regions, Earth Planet. Sci. Lett., 32, 51-61, $1976 a$.

Brooks, C., D. E. James, and S. R. Hart, Ancient lithosphere: Its role in young continental volcanism, Science, 193, 1086-1094, 1976 b.

Brueckner, H. K., Contact and fracture ultramafic assemblages from Norway: Rb-Sr evidence for crustal contamination, Contrib. Mineral. Petrol., 49, 39-48, 1975

Carlson, R. W., J. D. MacDougall, and G. W. Lugmair, Differential $\mathrm{Sm} / \mathrm{Nd}$ evolution in oceanic basalts, Geophys. Res. Lett., 5, 229232, 1978.

Carter, J. L., Mineralogy and chemistry of the Earth's upper mantle based on partial-fusion, partial-crystallization model, Geol. Soc. Amer. Bull., 81, 2021-2034, 1970.

Carter, S. R., N. M. Evenson, P. J. Hamilton, and R. K. O'Nions, Continental volcanics derived from enriched and depleted source regions: Nd- and Sr-isotope evidence, Earth Planet. Sci Lett., 37, 401-408, 1978.

Church, S. E., and M. Tatsumoto, Lead isotope relations in oceanic ridge basalts from the Juan de Fuca-Gorda Ridge area, N. E. Pacific Ocean, Contrib. Mineral. Petrol., 53, 253-279, 1975

Churkin, M., Jr., C. Carter, and B. Johnson, Subdivision of the Ordovician and Silurian time scale using accumulation rates of graptolitic shale, Geology, 5, 452-456, 1977

Coleman, R. G., Ophiolites, Springer, New York, 1977.

Consolmagno, G. J., and M. J. Drake, Equivalence of equations describing trace element distribution during equilibrium partial melting, Geochim. Cosmochim. Acta, 40, 1421-1422, 1976.

Dallmeyer, R. D., and $\mathrm{H}$. Williams, ${ }^{40} \mathrm{Ar} /{ }^{39} \mathrm{Ar}$ ages from the Bay of Islands metamorphic aureole: Their bearing on the timing of Ordovician ophiolite obduction, Can. J. Earth Sci., 12, 1685-1690, 1975.

Dasch, E. J., C. E. Hedge, and J. Dymond, Effect of sea water interaction on strontium isotope composition of deep-sea basalts, Earth Planet. Sci. Lett., 19, 177-183, 1973.

DePaolo, D. J., Implications of correlated $\mathrm{Nd}$ and $\mathrm{Sr}$ isotopic variations for the chemical evolution of the crust and mantle, Earth Planet. Sci. Lett., 43, 201-211, 1979.

DePaolo, D. J., and G. J. Wasserburg, Nd isotopic variations and petrogenetic models, Geophys. Res Lett., 3, 249-252, 1976 a.

DePaolo, D. J., and G. J. Wasserburg, Inferences about magma sources and mantle structure from variations of ${ }^{143} \mathrm{Nd} /{ }^{144} \mathrm{Nd}$, Geophys. Res. Lett., 3, 743-746, 1976 b.

DePaolo, D. J., and G. J. Wasserburg, The sources of island arcs as indicated by $\mathrm{Nd}$ and $\mathrm{Sr}$ isotopic studies, Geophys. Res. Lett., 4, 465$468,1977$.

DePaolo, D. J., and G. J. Wasserburg, Petrogenetic mixing models and Nd-Sr isotopic patterns, Geochim. Cosmochim. Acta, 43, 615627, $1979 a$.

DePaolo, D. J., and G. J. Wasserburg, Sm-Nd age of the Stillwater Complex and the mantle evolution curve for neodymium, Geochim. Cosmochim. Acta, 43, 999-1008, $1979 b$.

DePaolo, D. J., and G. J. Wasserburg, Nd isotopes in flood basalts from the Siberian Platform and inferences about their mantle sources, Proc. Nat. Acad. Sci. U.S., in press, 1979 c.

Dewey, J. F., and J. M. Bird, Origin and emplacement of the ophiolite suite: Appalachian ophiolites in Newfoundland, J. Geophys. Res., 76, 3179-3206, 1971.

Einarson, G. W., Low rank metamorphism in the Bay of Islands ophiolite complex, western Newfoundland, Geol. Ass. Can. Program Abstr., 752, 1975.

Engel, A. E. J., C. G. Engel, and R. G. Havens, Chemical characteristics of oceanic basalts and the upper mantle, Geol. Soc. Amer. Bull., 76, 719-734, 1965.

Frey, F. A., D. H. Green, and S. D. Roy, Integrated models of basalt petrogenesis: A study of olivine tholeiites to olivine melilitites from south eastem Australia utilizing geochemical and experimental petrologic data, J. Petrology, 19, 463-513, 1978.

Gast, P. W., Trace element fractionation and the origin of tholeiitic and alkaline magma types, Geochim. Cosmochim. Acta, 32, 10571086, 1968.

Griffin, W. L., and V. R. Murthy, Distribution of K, Rb, Sr, and Ba in some minerals relevant to basalt genesis, Geochim. Cosmochim. Acta, 33, 1389-1414, 1969.

Grutzeck, M., S. Kridelbaugh, and D. Weill, The distribution of Sr 
and REE between diopside and silicate liquid, Geophys. Res. Lett., I, 273-275, 1974.

Hamilton, P. J., R. K. O'Nions, and N. M. Evensen, Sm-Nd dating of Archean basic and ultrabasic volcanics, Earth Planet. Sci Lett., 36, 263-268, 1977.

Hamilton, P. J., R. K. O'Nions, N. M. Evensen, D. Bridgwater, and J. Allart, Sm-Nd isotopic investigations of the Isua supracrustals, West Greenland: Implications for mantle evolution, Nature, 272, 41-43, 1978.

Hamilton, P. J., N. M. Evensen, R. K. O'Nions, and J. Tarney, SmNd systematics of Lewisian gneisses: Implications for the origin of granulites, Nature, 277, 25-28, 1979.

Harris, P. G., A. Reay, and I. G. White, Chemical composition of the upper mantle, J. Geophys. Res., 72, 6359-6369, 1967.

Hart, S. R., Submarine basalts from Kilauea rift, Hawaii: Nondependence of trace element composition on extrusion depth, Earth Planet. Sci. Lett., 20, 201-203, 1973.

Hart, S. R., and C. Brooks, Clinopyroxene matrix partitioning of $\mathbf{K}$, Rb, Cs, Sr, and Ba, Geochim. Cosmochim. Acta, 38, 1799-1803, 1974.

Hart, S. R., C. Brooks, T. E. Krogh, G. L. Davis, and D. Nava, Ancient and modern volcanic rocks: A trace element model, Earth Planet. Sci. Lett., 10, 17-28, 1970.

Hart, S. R., W. E. Glassley, and D. E. Karig, Basalts and sea floor spreading behind the Mariana Island arc, Earth Planet. Sci. Lett., 15, 12-18, 1972.

Hart, S. R., A. J. Erlank, and E. J. D. Kable, Sea floor basalt alteration: Some chemical and $\mathrm{Sr}$ isotopic effects, Contrib. Mineral. Petrol., 44, 219-230, 1974.

Hawkesworth, C. J., R. K. O'Nions, R. J. Pankhurst, P. J. Hamilton, and N. M. Evensen, A geochemical study of island-arc and backarc tholeiites from the Scotia Sea, Earth Planet. Sci. Lett., 36, 253262, 1977.

Hawkesworth, C. J., M. J. Norry, J. C. Roddick, and R. Vollmer, The significance of trace element modeling calculations for the evolution of $\mathrm{Sr}$ and $\mathrm{Nd}$ isotopes in the mantle, Open File Rep. 78-701, pp 162-164, U.S. Geol. Surv., Reston, Va., 1978.

Hawkins, J. W., Petrology and geochemistry of basaltic rocks of the Lau Basin, Earth Planet. Sci. Lett., 28, 283-297, 1976.

Herrmann, A. G., Yttrium and lanthanides, 39, 57-71, in Handbook of Geochemistry, vol. II, part 5, edited by K. H. Wedepohl, Springer, New York, 1969-1974.

Hildreth, R. A., and W. T. Henderson, Comparison of ${ }^{87} \mathrm{Sr} /{ }^{86} \mathrm{Sr}$ for seawater strontium and the Eimer and Amend $\mathrm{SrCO}_{3}$, Geochim. Cosmochim. Acta, 35, 235-238, 1971.

Høgdahl, O. T., B. T. Bowen, and S. Melson, Neutron activation analysis of lanthanide elements in sea water, Advan. Chem. Ser., 73, 308-325, 1968.

Holland, H., The Chemistry of the Atmosphere and Oceans, John Wiley, New York, 1978.

Hubbard, N. J., and P. W. Gast, Chemical composition and origin of nonmare lunar basalts, Proc. Lunar Sci. Conf. 2nd, 2, 999-1020, 1971.

Irvine, T. N., and T. C. Findlay, Alpine-type peridotite with particular reference to the Bay of Islands complex, Publ. 42, pp. 97-128, Earth Phys. Br., Dep. of Energ., Mines, and Resour., Ottawa, Ont., Canada, 1972.

Jackson, E. D., and T. L. Wright, Xenoliths in the Honolulu volcanic series, J. Petrology, II, 405-430, 1970.

Jacobsen, S. B., and G. J. Wasserburg, The mean age of mantle and crustal reservoirs, J. Geophys. Res., 84, this issue, 1979.

Karson, J., and J. F. Dewey, Coastal Complex, western Newfoundland: An early Ordovician oceanic fracture zone, Geol. Soc. Amer. Bull., 89, 1037-1049, 1978.

Kay, R. W., and R. G. Senechal, The rare earth chemistry of the Troodos ophiolite complex, J. Geophys. Res., 81, 964-970, 1976.

Kay, R., N. J. Hubbard, and P. W. Gast, Chemical characteristics and origin of oceanic ridge volcanic rocks, J. Geophys. Res., 75, 15851613,1970

Leeman, W. P., Petrogenesis of McKinney (Snake River) olivine tholeiite in light of rare-earth element and $\mathrm{Cr} / \mathrm{Ni}$ distributions, Geol. Soc. Amer. Bull., 87, 1582-1586, 1976.

Lugmair, G. W., Sm-Nd ages: A new dating method (abstract), Meteoritics, 9, 369, 1974.

Lugmair, G. W., K. Marti, J. P. Kurtz, and N. B. Scheinin, History and genesis of lunar troctolite 76535 or: How old is old?, Proc. Lunar Sci. Conf. 7th, 2009-2033, 1976.
Maaløe, S., and K. Aoki, The major element composition of the upper mantle estimated from the composition of lherzolites, Contrib. Mineral. Petrol., 63, 161-173, 1977.

Malpas, J., Magma generation in the upper mantle, field evidence from ophiolite suites, and application to the generation of oceanic lithosphere, Phil. Trans. Roy. Soc. London, Ser. A, 288, 527-546, 1978.

Masuda, A., and H. Jibiki, Rare-earth patterns of Mid-Atlantic Ridge gabbros: Continental nature?, Geochem. J., 7, 55-65, 1973.

Mattinson, J. M., Early Paleozoic ophiolite complexes of Newfoundland: Isotopic ages of zircons, Geology, 3, 181-183, 1975.

Mattinson, J. M., Ages of zircons from the Bay of Islands Ophiolite Complex, western Newfoundland, Geology, 4, 393-394, 1976.

McCulloch, M. T., and G. J. Wasserburg, Sm-Nd and Rb-Sr chronolbgy of continental crust formation, Science, 200, 1003-1011, 1978.

McDougall, I., Geochemistry and origin of basalt of the Columbia River Group, Oregon and Washington, Geol. Soc. Amer. Bull., 87, 777-792, 1976.

McKay, G. A., and D. F. Weill, Petrogenesis of KREEP, Proc. Lunar Sci. Conf. 7ih, 2427-2447, 1976.

Menzies, M. M., and V. R. Murthy, Strontium isotope geochemistry of alpine tectonite lherzolites: Data compatible with a mantle origin, Earth Planet. Sci. Lett., 38, 346-954, 1978.

Montigny, R., H. Bougault, Y. Bottinga, and C. J. Allègre, Trace element geochemistry and genesis of the Pindos ophiolite suite, Geochim. Cosmochim. Acta, 37, 2135-2 [147, 1973.

Nakamura, N., Determination of REE, Ba, $\mathrm{Fe}, \mathrm{Mg}, \mathrm{Na}$ and $\mathrm{K}$ in carbonaceous and ordinary chondrites, Geochim. Cosmochim. Acta, 38, 757-775, 1974.

O'Nions, R. K., R. J. Pankhurst, and K. Grønvold, Nature and development of basalt magma sources beneath Iceland and the Reykjanes Ridge, J. Petrology, 17, 315-338, 1976.

O'Nions, R. K., P. J. Hamilton, and N. M. Evensen, Variations in ${ }^{143} \mathrm{Nd} /{ }^{144} \mathrm{Nd}$ and ${ }^{87} \mathrm{Sr} /{ }^{86} \mathrm{Sr}$ ratios in oceanic basalts, Earth Planet. Sci. Lett., 34, 13-22, 1977.

O'Nions, R. K., S. R. Carter, R. S. Cohen, N. M. Evensen, and P. J. Hamilton, $\mathrm{Pb}$, Nd and $\mathrm{Sr}$ isotopes in oceanic ferromanganese deposits and ocean floor basalts, Nature, 273, 435-438, 1978a.

O'Nions, R. K., N. M. Evensen, P. J. Hamilton, and S. R. Carter, Melting of the mantle past and present: Isotope and trace element evidence, Phil Trans. Roy. Soc. London, Ser. A, 288, 547-559, $1978 b$.

Papanastassiou, D. A., and G. J. Wasserburg, Rb-Sr ages and initial strontium in basalts from Apollo 15, Earth Planet. Sci. Lett., 17, 324-337, 1973.

Papanastassiou, D. A., G. J. Wasserburg, and D. S. Burnett, Rb-Sr ages of lunar rocks from the Sea of Tranquility, Earth Planet. Sci. Lett., 8, 1-9, 1970.

Papanastassiou, D. A., D. J. DePaolo, and G. J. Wasserburg, Rb-Sr and Sm-Nd chronology and genealogy of basalts from the Sea of Tranquility. Proc. Lunar Sci. Conf. 8th, 1639-1672, 1977.

Philpotts, J. A., and C. C. Schnetzler, Phenocryst-matrix partition coefficients for $\mathrm{K}, \mathrm{Rb}, \mathrm{Sr}$ and $\mathrm{Ba}$, with applications to anorthosite and basalt genesis, Geochim. Cosmochim. Acta, 34, 307-322, 1970.

Piepgras, D. J., G. J. Wasserburg, and E. J. Dasch, The isotopic composition of Nd in different ocean masses, Earth Planet. Sci. Lett., in press, 1979.

Richard, P., N. Shimizu, and C. J. Allègre, ${ }^{143} \mathrm{Nd} /{ }^{146} \mathrm{Nd}$, a natural tracer, an application to oceanic basalts, Earth Planet. Sci. Lett., 31, 269-278, 1976.

Richard, P., D. Rousseau, and C. J. Allègre, Nd and St systematics in ophiolites, Open File Rep. 78-701, p. 350, U.S. Geol. Surv., Reston, Va., 1978.

Ringwood, A. E., Composition and Petrology of the Earth's Mantle, 618 pp., McGraw-Hill, New York, 1975.

Salisbury, M. H., and N. I. Christensen, The seismic velocity structure of a traverse through the Bay of Islands Ophiolite Complex, Newfoundland, an exposure of oceanic crust and upper mantle, $J$. Geophys. Res., 83, 805-817, 1978.

Schilling, J. G., Iceland mantle plume: Geochemical study of the Reykjanes Ridge, Nature, 242, 565-571, 1973.

Schnetzler, C. C., and J. A. Philpotts, Partition coefficients of rareearth elements between igneous matrix material and rock-forming phenocrysts, II, Geochim. Cosmochim. Acta, 34, 331-340, 1970.

Shaw, D. M., Trace element fractionation during anatexis, Geochim. Cosmochim. Acta, 34, 237-243, 1970.

Shimizu, N., An experimental study of the partitioning of $\mathrm{K}, \mathrm{Rb}, \mathrm{Cs}$, 
$\mathrm{Sr}$ and $\mathrm{Ba}$ between clinopyroxene and liquid at high pressures, Geochim. Cosmochim. Acta, 38, 1789-1798, 1974.

Shimizu, N., and I. Kushiro, The partition of rare earth elements between garnet and liquid at high pressures: Preliminary experiments, Geophys. Res. Lett., 2, 413-416, 1975.

Smith, C. H., Bay of Islands igneous complex, western Newfoundland, Geol. Surv. Can. Mem., 290, 132 pp., 1958.

Spooner, E. T. C., R. D. Beckinsale, W. S. Fyfe, and J. D. Smewing, $\mathrm{O}^{1 \mathrm{R}}$-enriched ophiolitic metabasic rocks from E. Liguria (Italy), Pindos (Greece), and Troodos (Cyprus), Contrib. Mineral. Petrol., $47,41-62,1974$.

Spooner, E. T. C., H. J. Chapman, and J. D. Smewing, Strontium isotopic contamination and oxidation during ocean floor hydrothermal metamorphism of the ophiolitic rocks of the Troodos Massif, Cyprus, Geochim. Cosmochim. Acta, 41, 873-890, 1977.

Stevens, R. K., Cambro-Ordovician flysch sedimentation and tectonics in west Newfoundland and their possible bearing on a proto-Atlantic ocean, Flysch Sedimentology in North America, Geol. Ass. Can. Spec. Pap. 7, 165-177, 1970.

Stukas, V., and P. H. Reynolds, ${ }^{40} \mathrm{Ar} /{ }^{39} \mathrm{Ar}$ dating of the Long Range dikes, Newfoundland, Earth Planet. Sci. Lett., 22, 256-266, 1974a.

Stukas, V., and P. H. Reynolds, ${ }^{40} \mathrm{Ar} /{ }^{39} \mathrm{Ar}$ dating of the Brighton gabbro complex, Lushs Bight terrane, Newfoundland, Can. J. Earth Sci., 11, 1485-1488, 1974b.

Sun, S. S., and G. N. Hanson, Evolution of the mantle: Geochemical evidence from alkali basalts, Geology, 3, 297-302, 1975.

Sun, S. S., and B. Jahn, Lead and strontium isotopes in post-glacial basalts from Iceland, Nature, 255, 527-530, 1975.

Sun, S. S., M. Tatsumoto, and J. G. Schilling, Mantle plume mixing along the Reykjanes Ridge axis: Lead isotopic evidence, Science, $190,143-147,1975$.

Tatsumoto, M., Isotopic composition of lead in oceanic basalt and its implication to mantle evolution, Earth Planet. Sci. Lett., 38, 63-87, 1978.

Tatsumoto, M., C. E. Hedge, and A. E. J. Engel, K, Rb, Sr, Th, U and ${ }^{87} \mathrm{Sr} /{ }^{86} \mathrm{Sr}$ in oceanic tholeiitic basalt, Science, $150,886-888,1965$.

Veizer, J., and W. Compston, ${ }^{87} \mathrm{Sr} /{ }^{86} \mathrm{Sr}$ composition of seawater during the Phanerozoic, Geochim. Cosmochim. Acta, 38, 1461-1484, 1974.
Wasserburg, G. J., and D. A. Papanastassiou, Model ages, Nature, $259,159-160,1976$.

Weill, D. F., and G. A. McKay, The partitioning of $\mathrm{Mg}, \mathrm{Fe}, \mathrm{Sr}, \mathrm{Ce}$, $\mathrm{Sm}, \mathrm{Eu}$ and $\mathrm{Yb}$ in lunar igneous systems and a possible origin of KREEP by equilibrium partial melting, Proc. Lunar Sci. Conf. 6th, 1143-1158, 1975.

Wenner, D. B., and H. P. Taylor, Jr., Oxygen and hydrogen isotope studies of serpentinization of ultramafic rocks in oceanic environments and continental ophiolite complexes, Amer. J. Sci., 273, 207239, 1973.

White, W. M., and J. G. Schilling, The nature and origin of geochemical variation in Mid-Atlantic Ridge basalts from the central north Atlantic, Geochim. Cosmochim. Acta, 42, 1501-1516, 1978.

Williams, H., The Bay of Islands map area, Newfoundland, Geol. Surv. Can. Pap., 72-34, 1-7, 1973.

Williams, $H$., and J. Malpas, Sheeted dikes and brecciated dike rocks within transported igneous complexes, Bay of Islands, western Newfoundland, Can. J. Earth Sci., 9, 1216-1229, 1972.

Williams, H., and R. K. Stevens, Geology of Belle Isle-Northern extremity of the deformed Appalachian miogeosynclinal belt, Can. J. Earth Sci., 6, 1145-1157, 1969.

Williams, H., and R. K. Stevens, The ancient continental margin of eastern North America, in The Geology of Continental Margins, edited by C. Burke and C. Drake, pp. 781-796, Springer, New York, 1974

Williams, H., and R. W. Talkington, Distribution and tectonic setting of ophiolites and ophiolitic melanges in the Appalachian orogen, North American Ophiolites, Oreg. Dep. Geol. Min. Ind. Bull., 95, 1 $11,1977$.

York, D., Least-squares fitting of a straight line, Can. J. Phys., 44, 1079-1086, 1966.

Zindler, A., C. Brooks, N. T. Arndt, and S. Hart, Nd and Sr isotope data from komatiitic and tholeiitic rocks of Munro Township, Ontario, Short Papers of the Fourth International Conference, Geochronology, Cosmochronology, Isotope Geology, Open File Rep. 78 701, 476 pp., U.S. Geol. Surv., Reston, Va., 1978.

(Received May 10, 1979; revised July 27, 1979; accepted July $31,1979$. 